Western University

Scholarship@Western

Political Science Publications

Political Science Department

2010

\title{
The NATO Club and Afghanistan: Northern, Rich, and White Nations Defend the Imperial Palace
}

Erika Simpson

Political Science, simpson@uwo.ca

Follow this and additional works at: https://ir.lib.uwo.ca/politicalsciencepub

Part of the Political Science Commons

Citation of this paper:

Simpson, Erika, “The NATO Club: 'northern', 'rich', 'white nations defending the Imperial Palace?” ed. Darren Marks, War, Human Dignity, and Nation Building: Theological Perspectives on Canada's Role in Afghanistan” (Cambridge Scholars Publishing) 2010, pp. 70-89. 

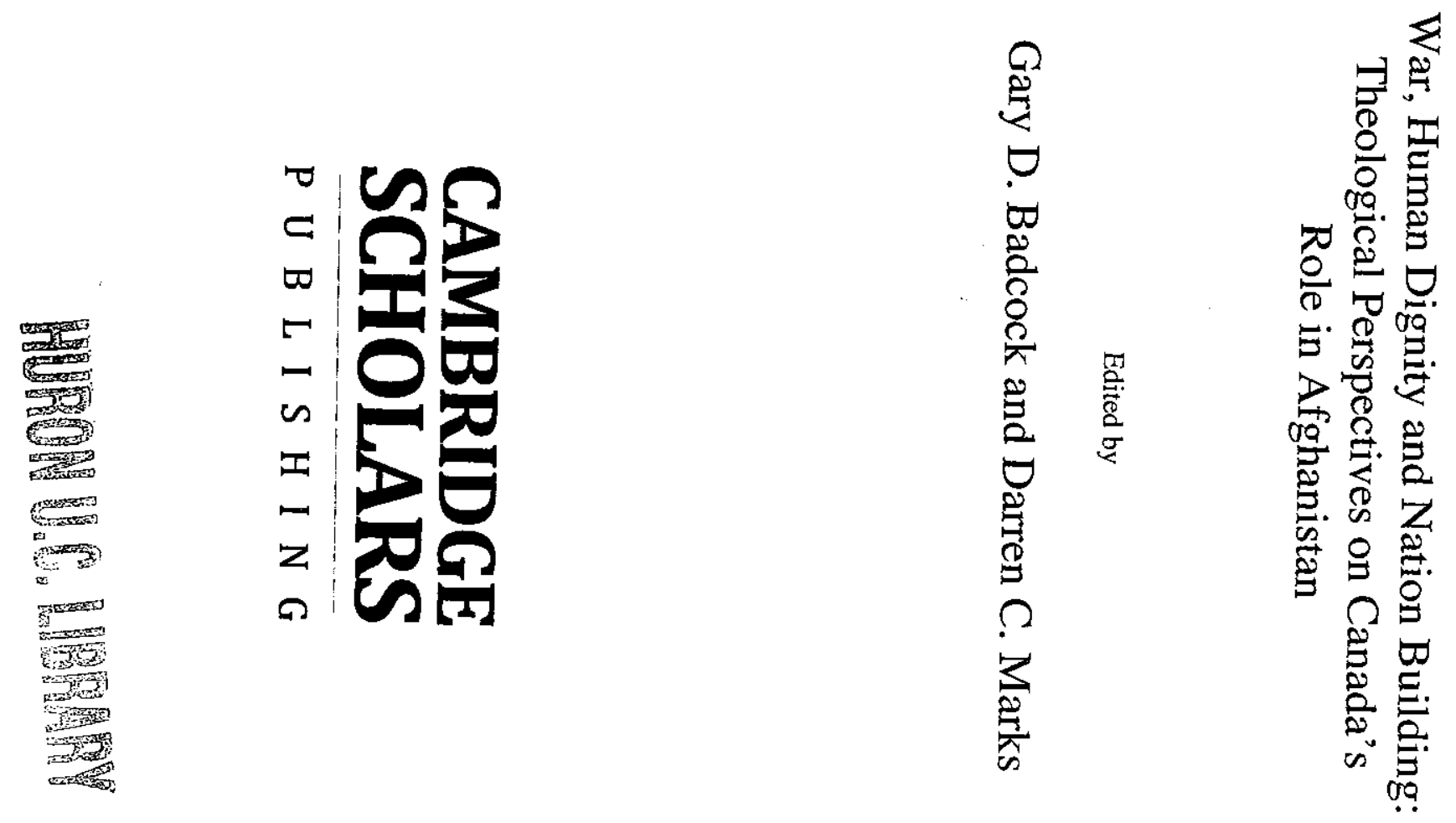


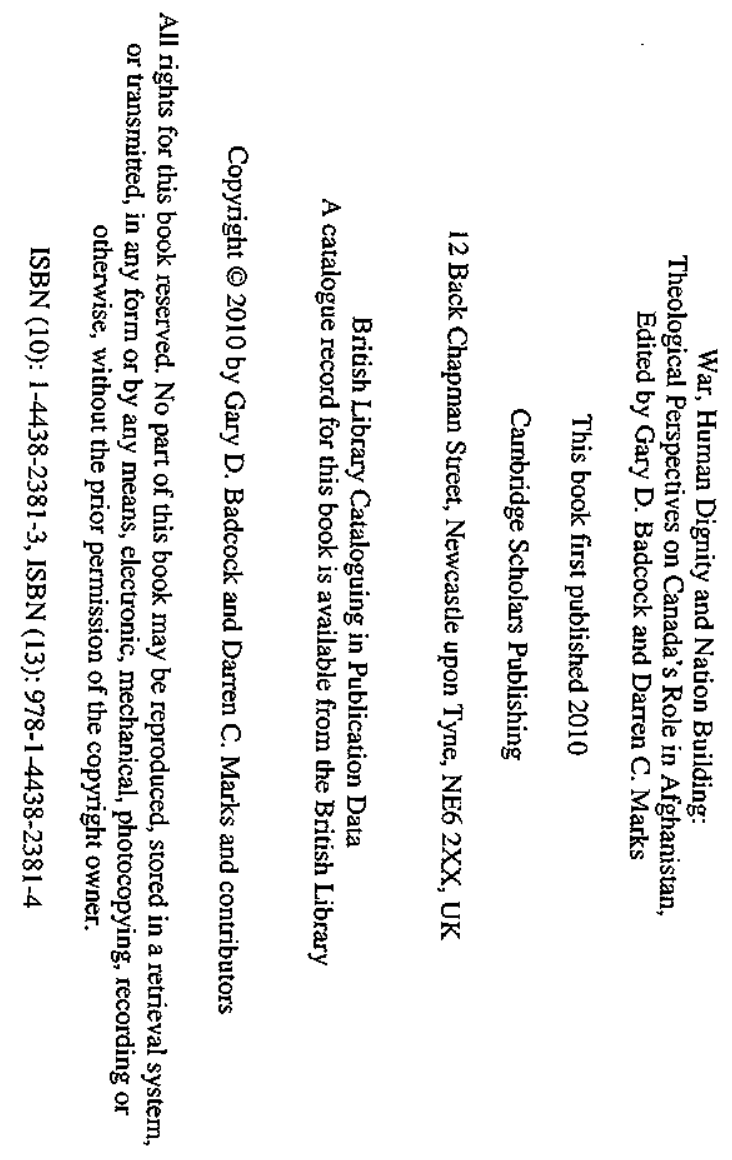

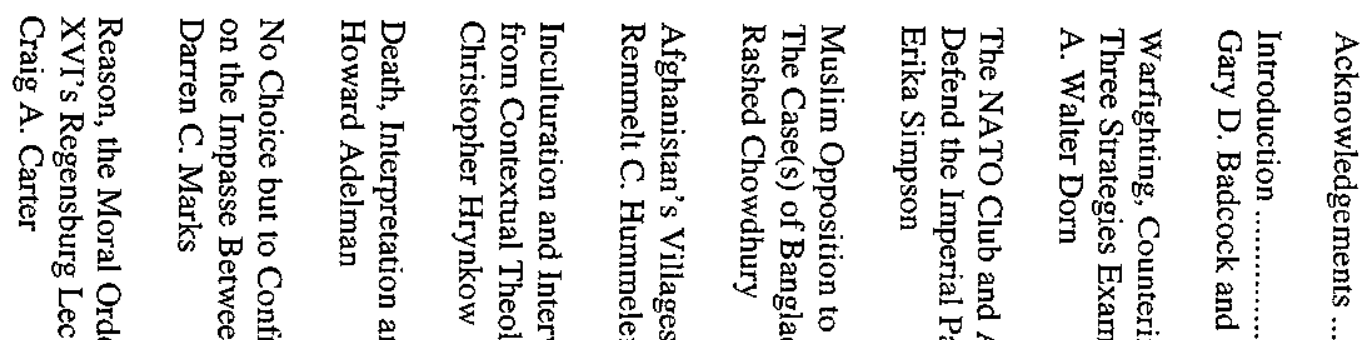

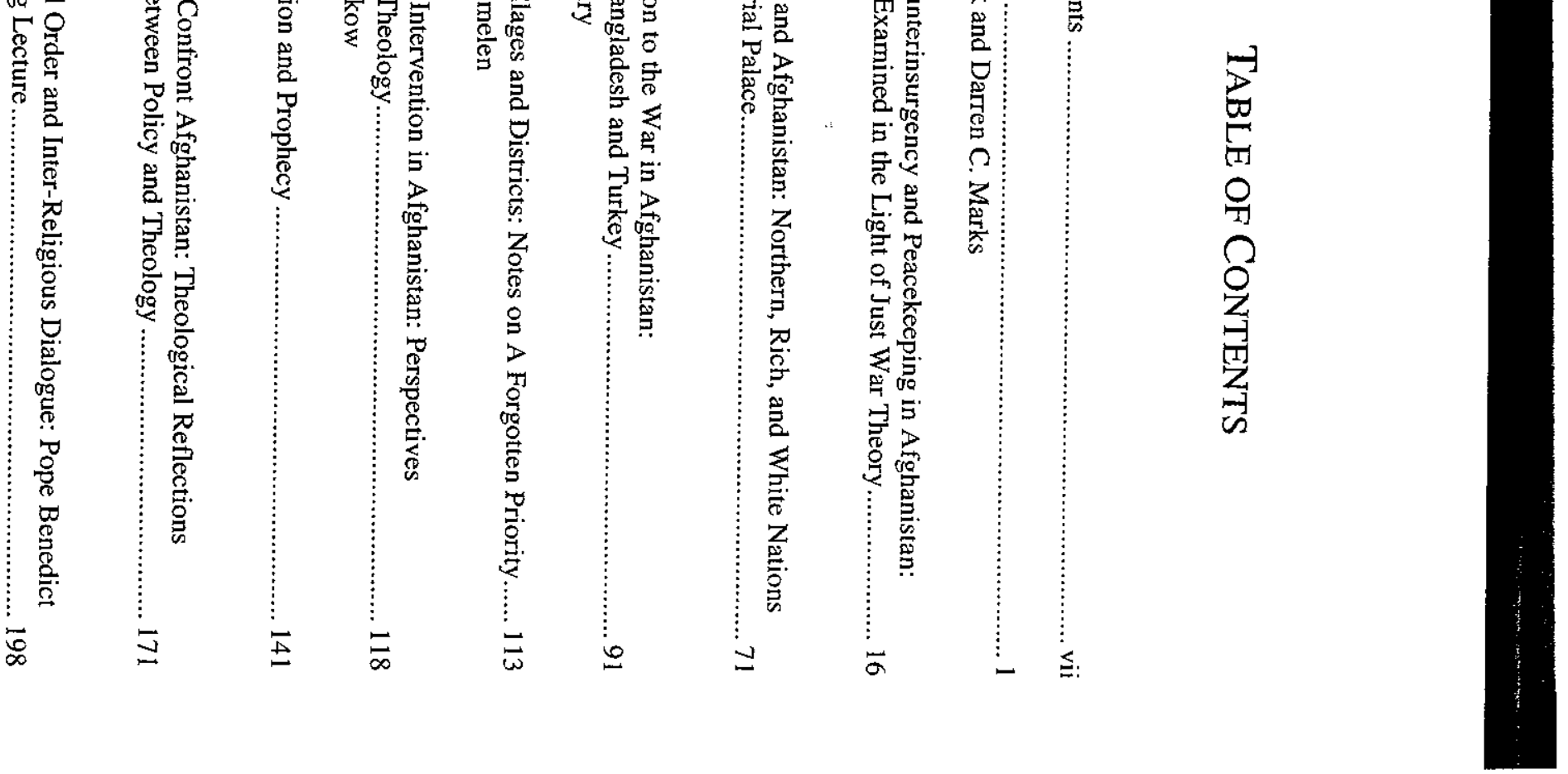




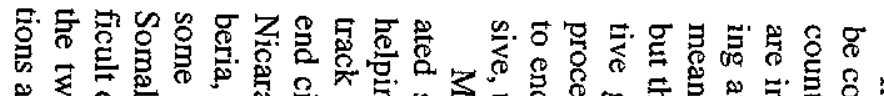

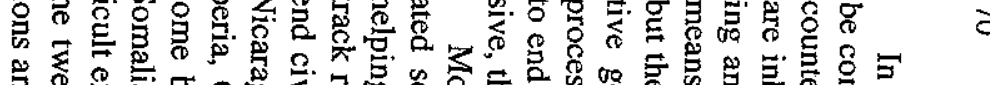

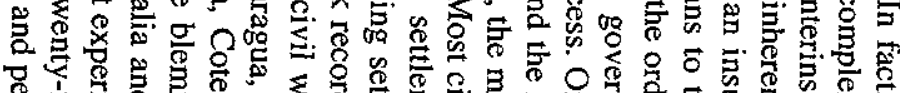

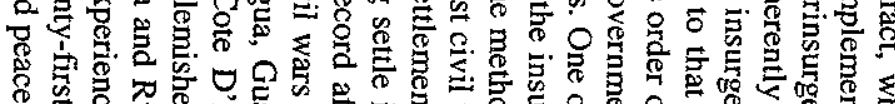

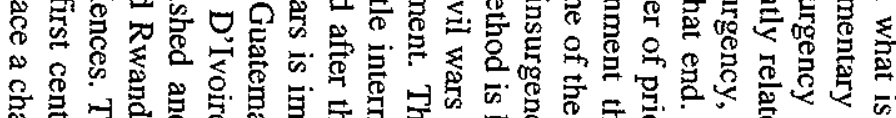

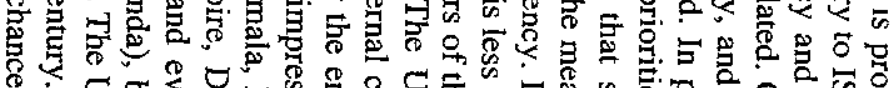

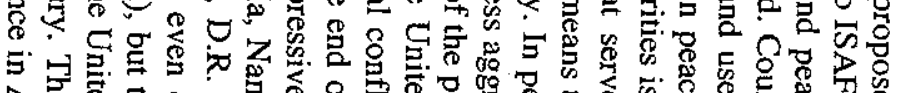

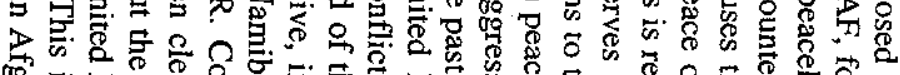
雪

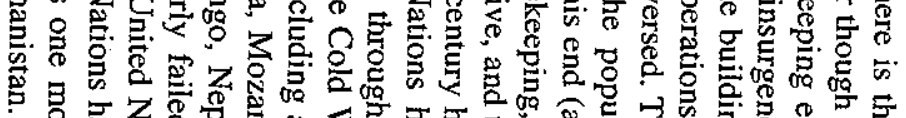

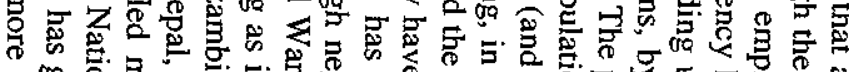

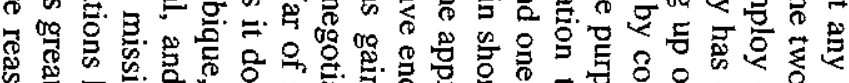

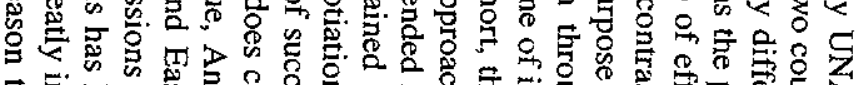

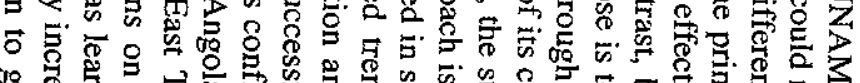

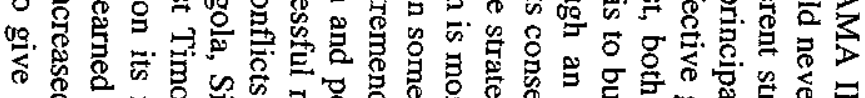

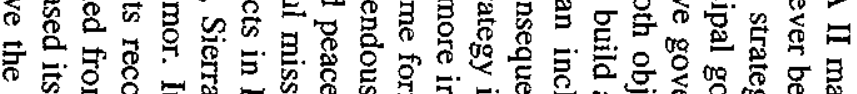

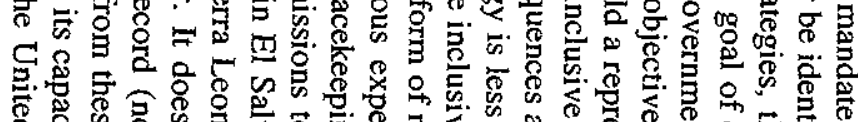

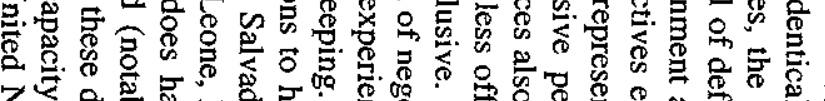

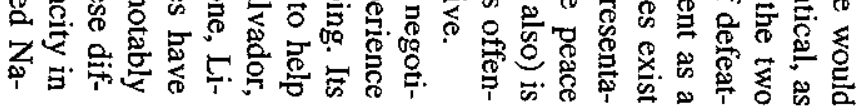

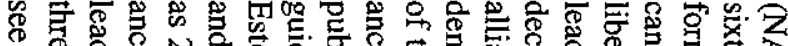

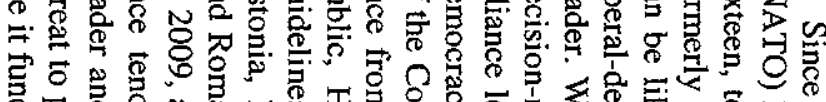

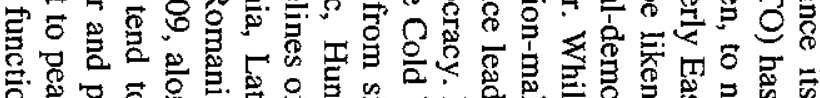

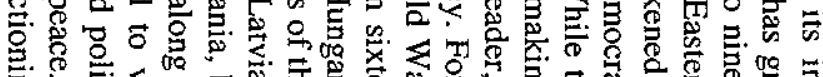

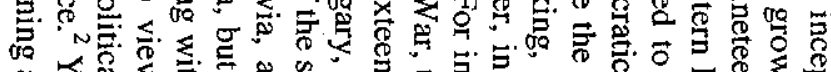

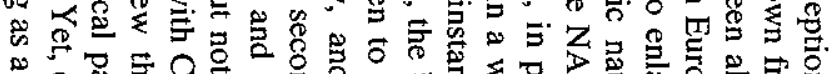

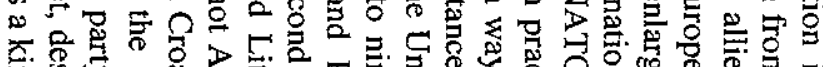

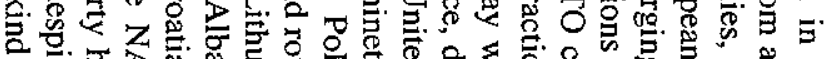

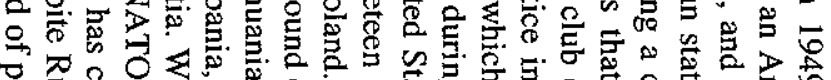

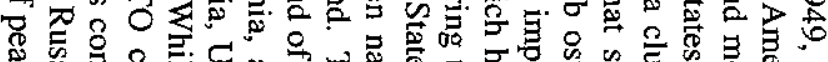

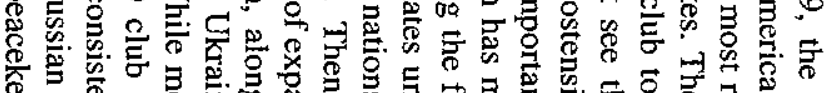

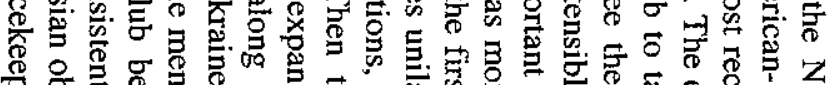

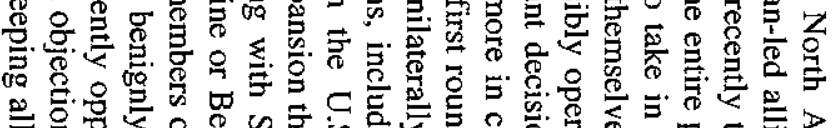

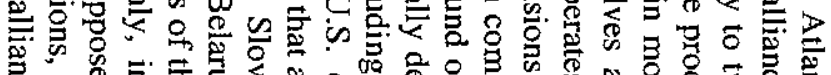

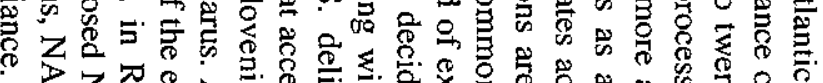

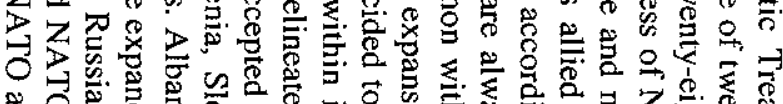

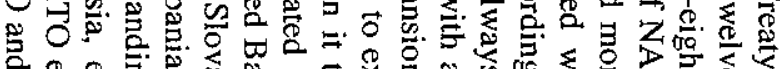

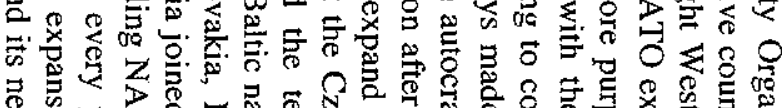

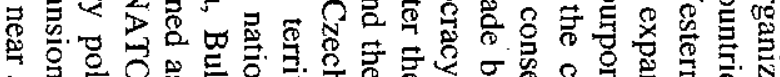

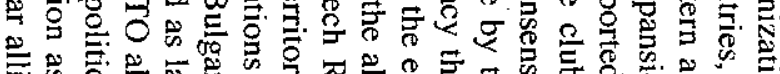
蛋 䨌

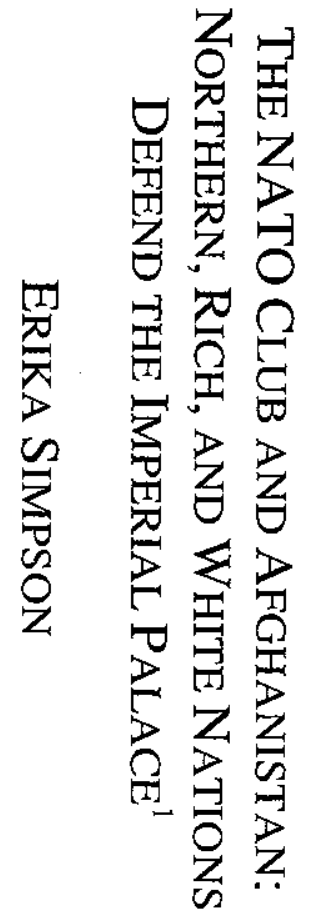




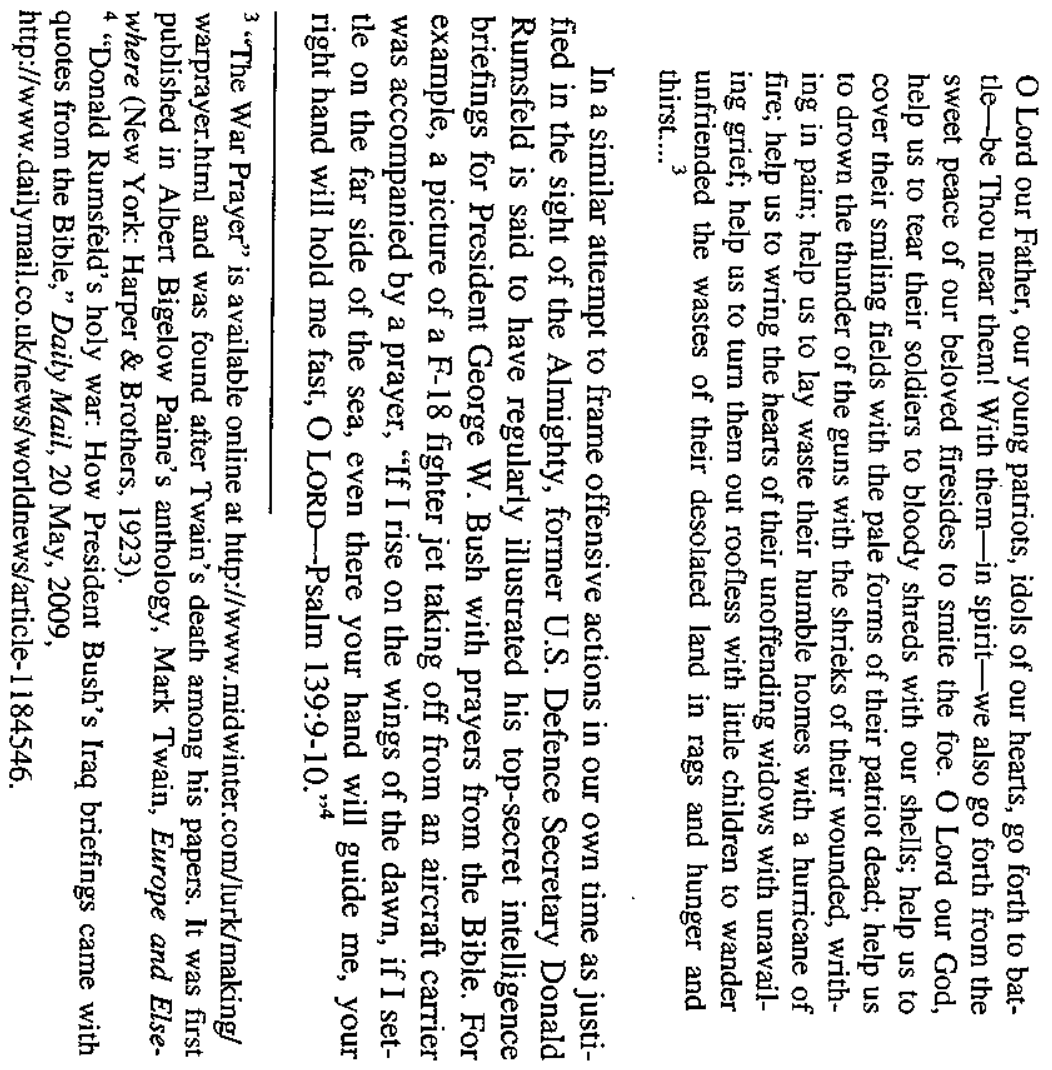

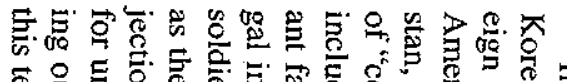

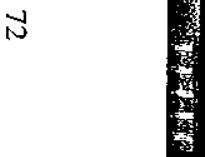

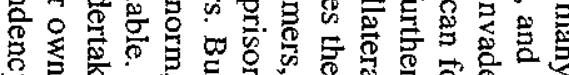

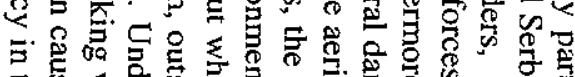

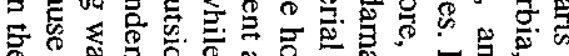

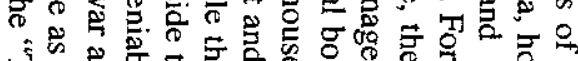

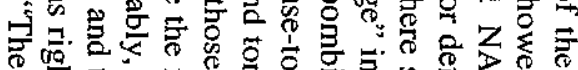

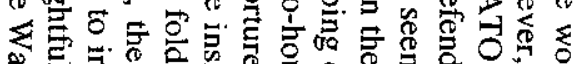

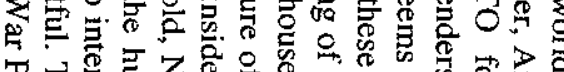

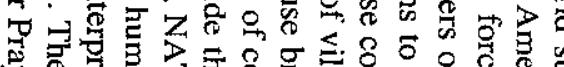

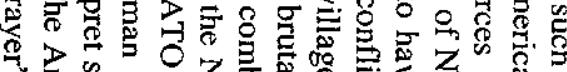

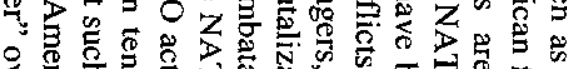

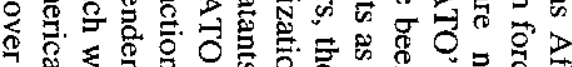

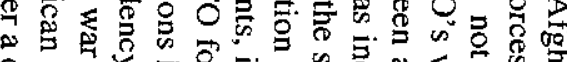

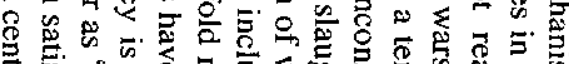

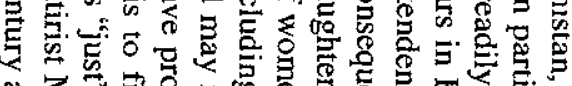

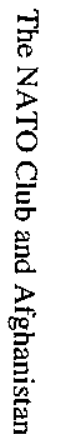

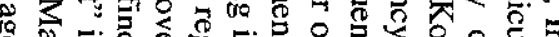

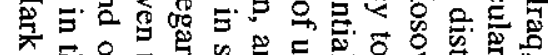

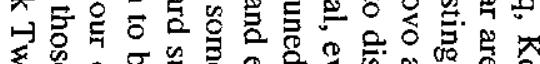

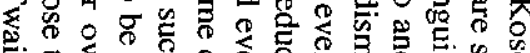

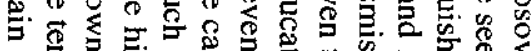

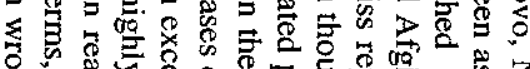

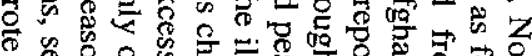

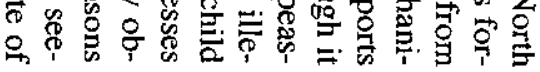

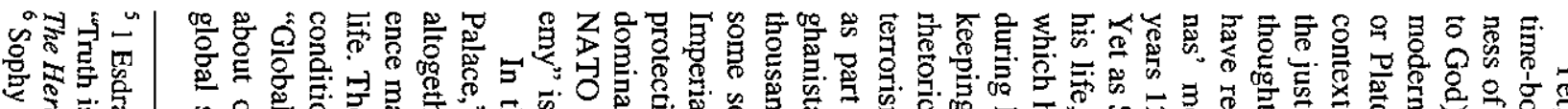

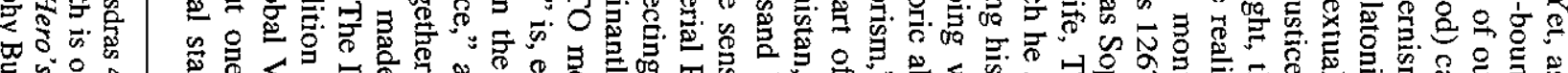

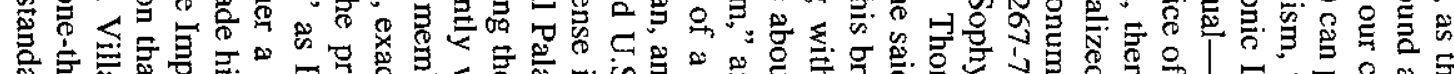

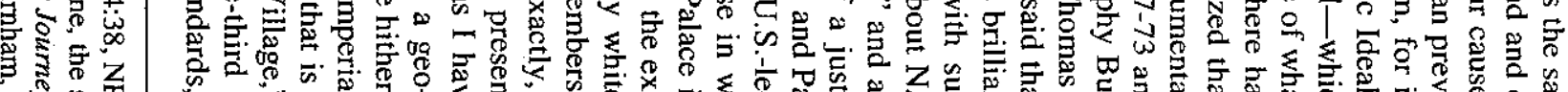

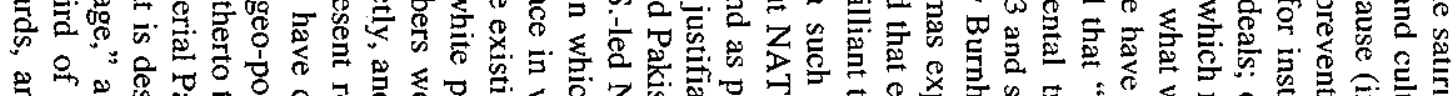

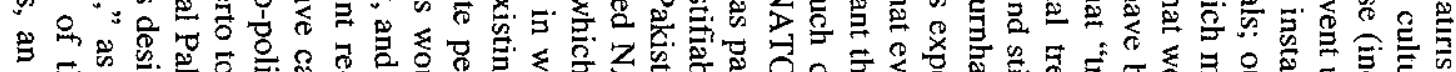

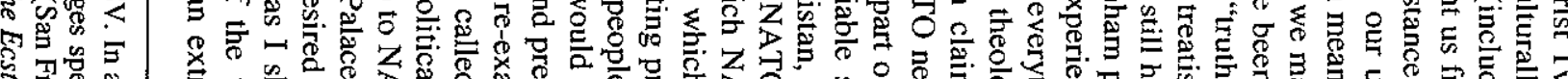

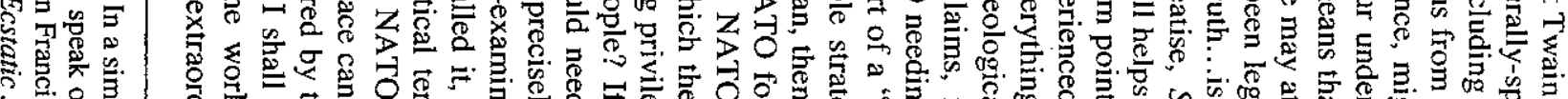

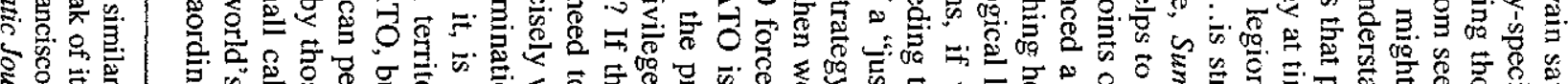

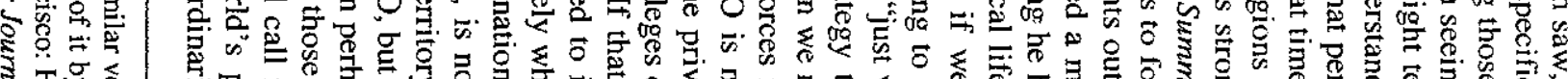

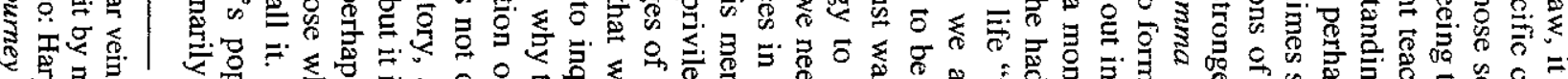

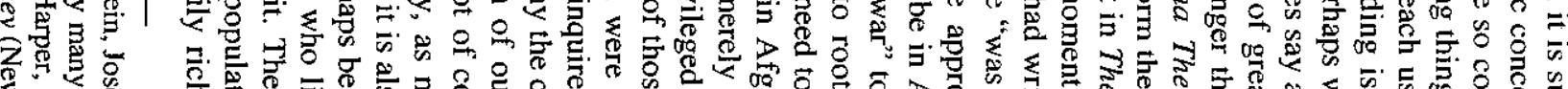

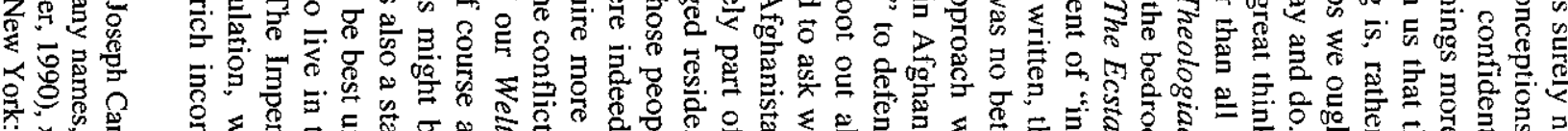

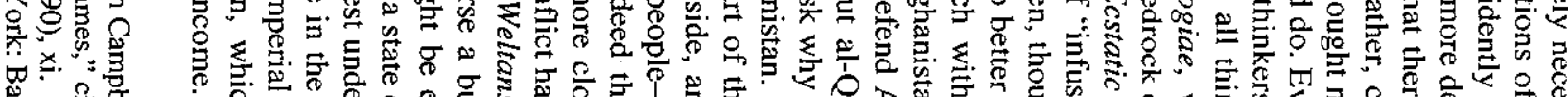

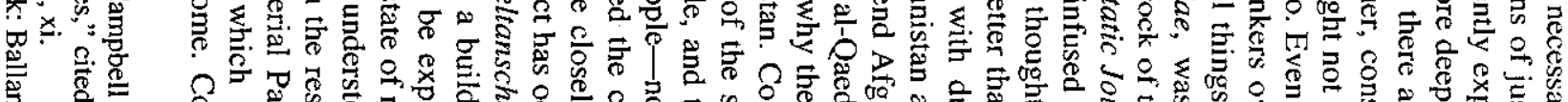

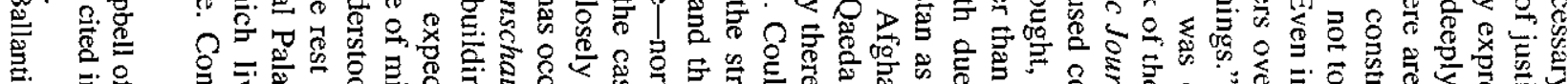

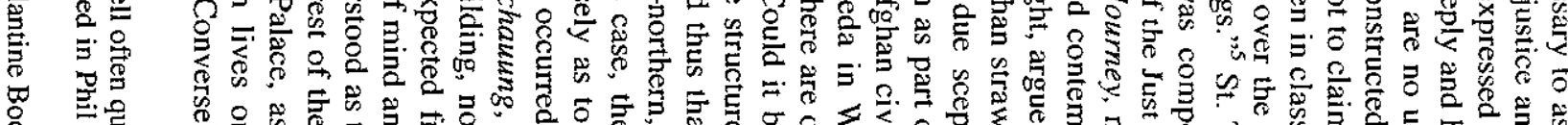

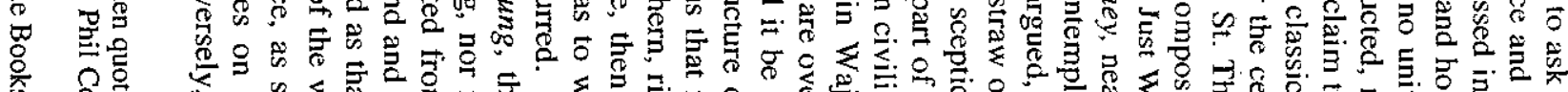

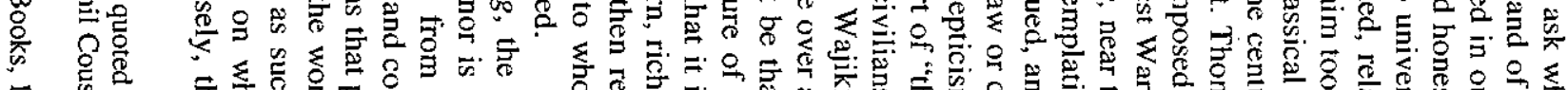

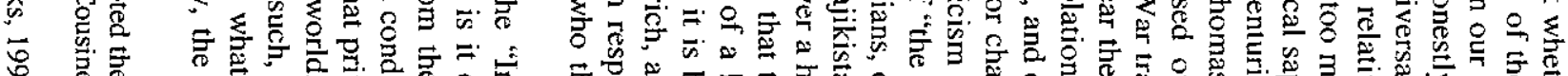

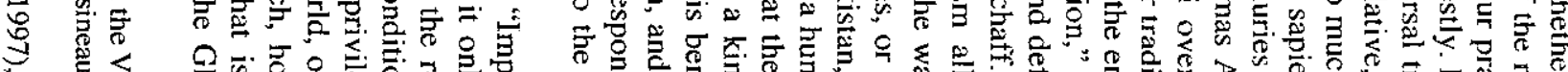

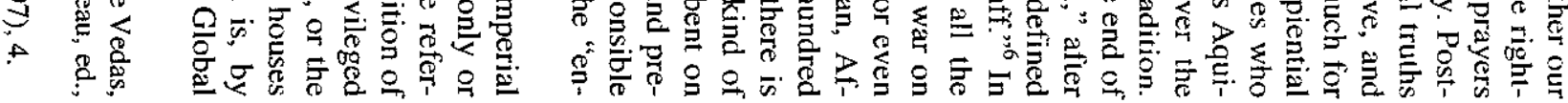




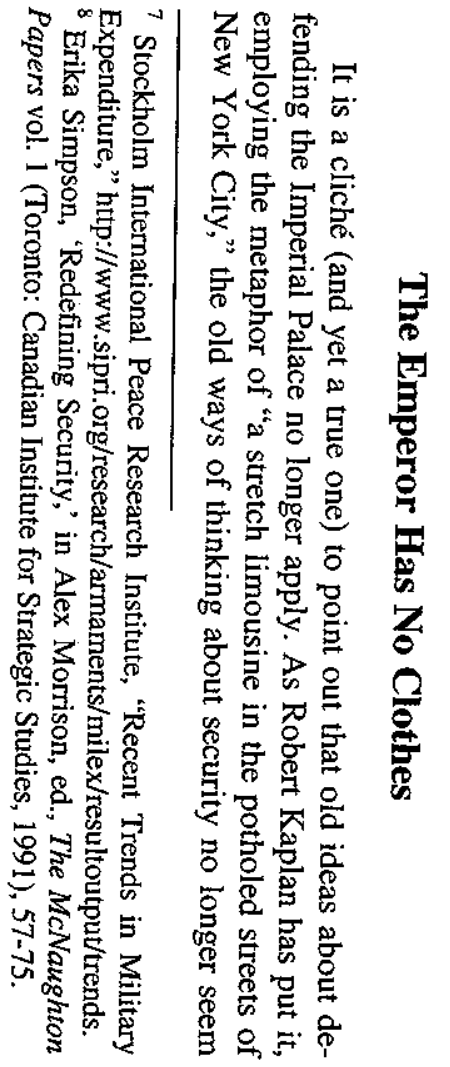

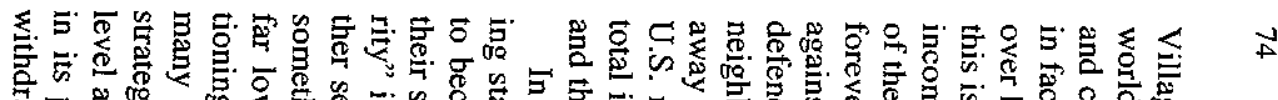

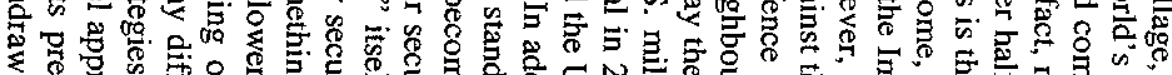

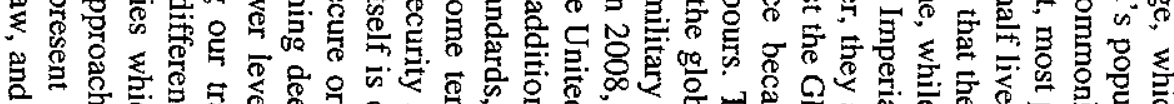

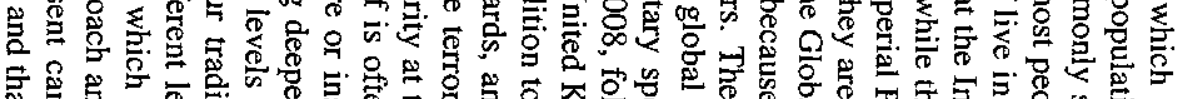

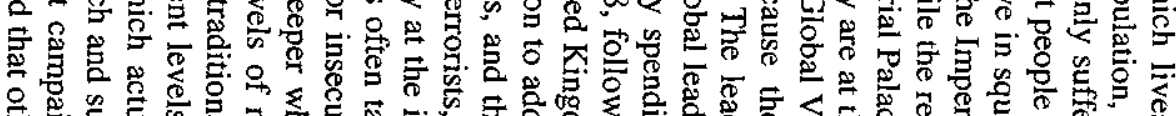

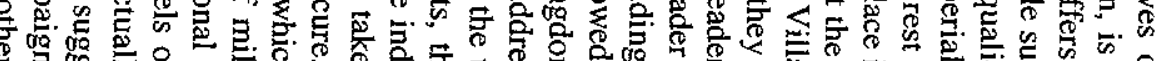

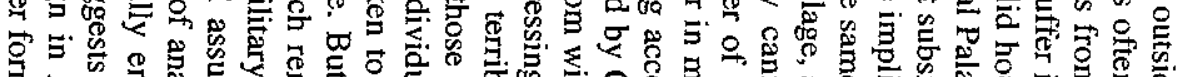

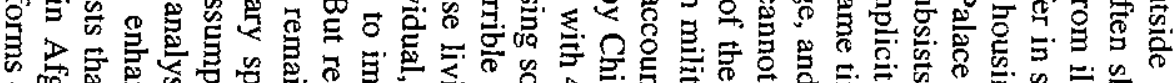

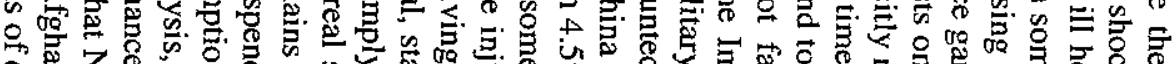

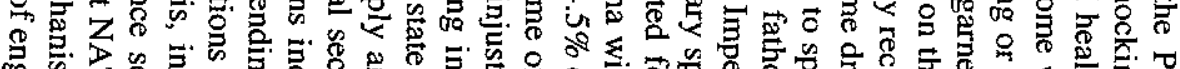

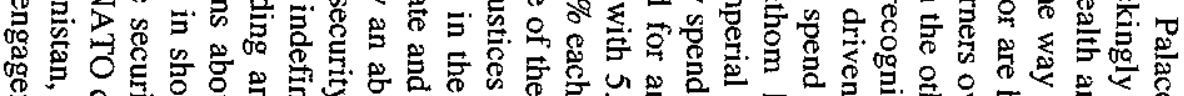

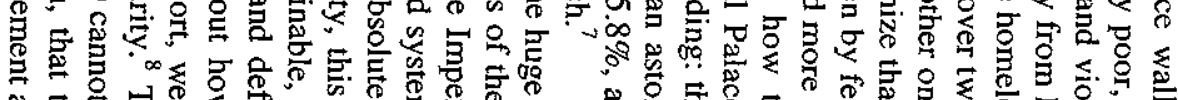

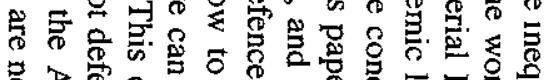

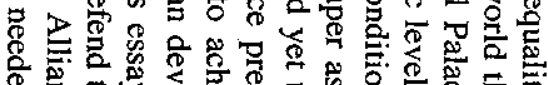

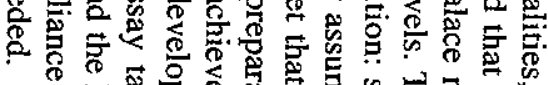

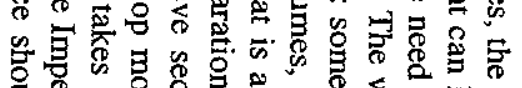

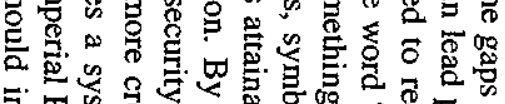

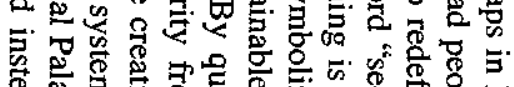

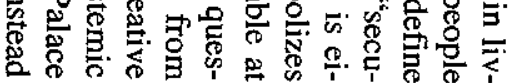

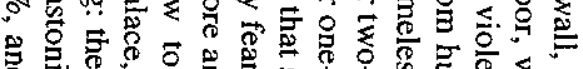

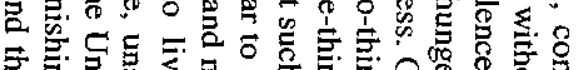

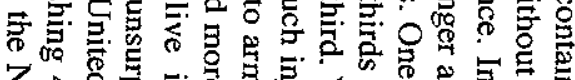

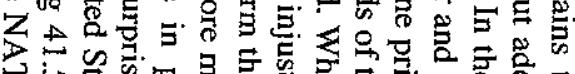

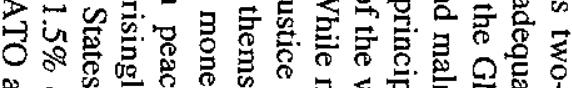

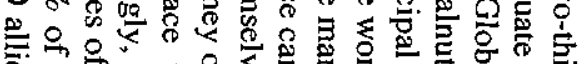

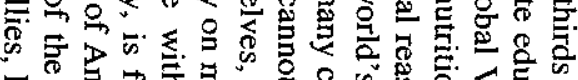
דะ

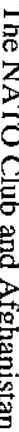
W

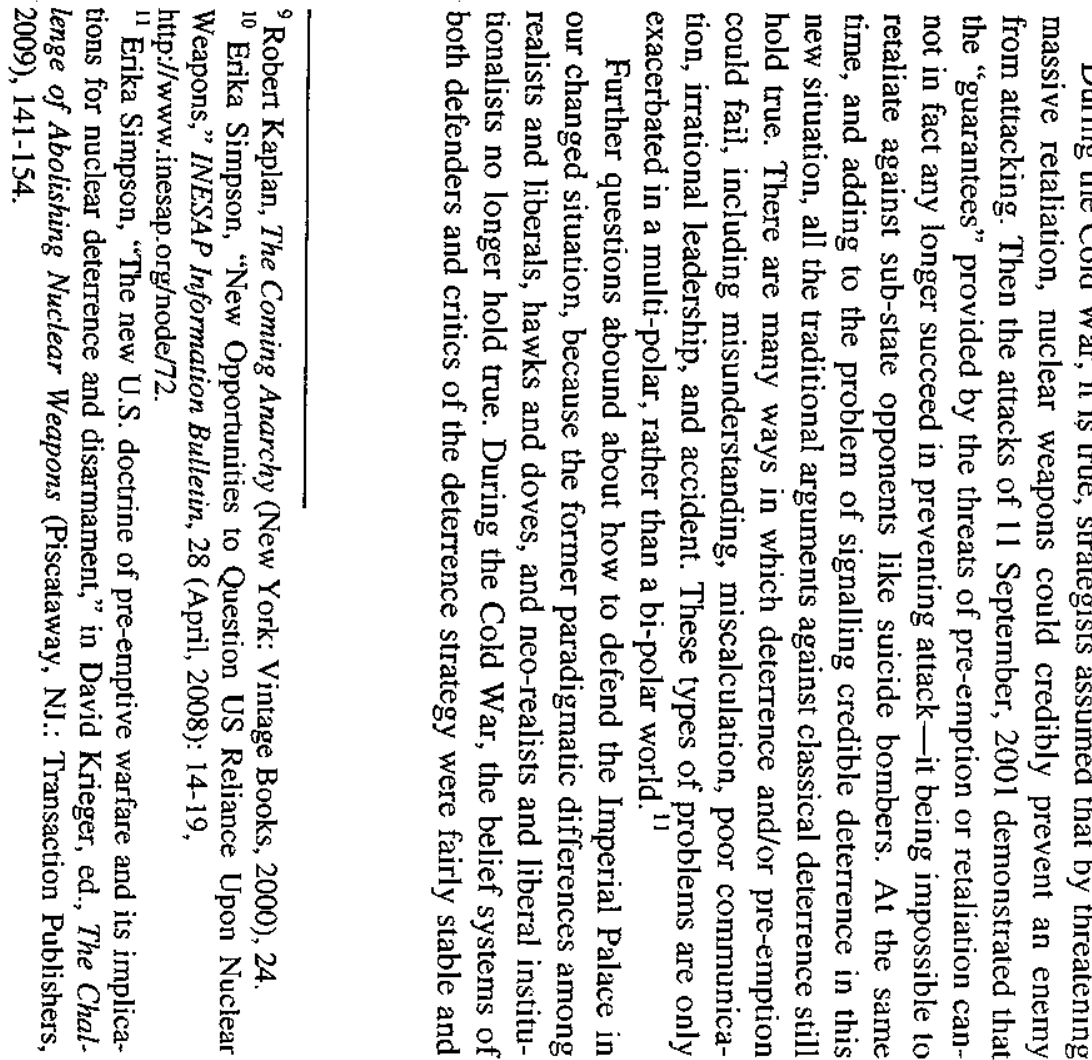

.

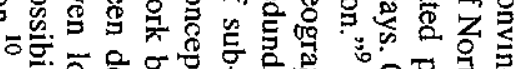

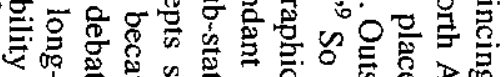

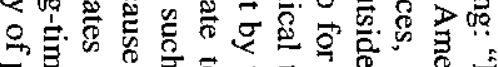
प्र

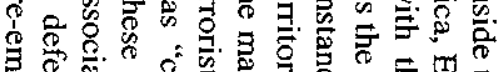

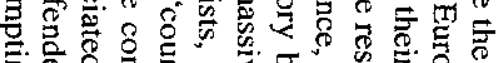

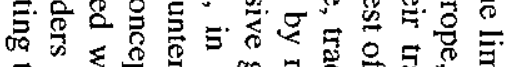

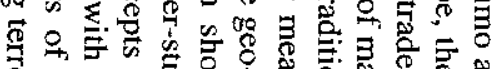

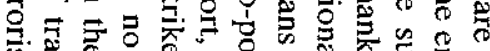

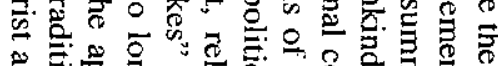

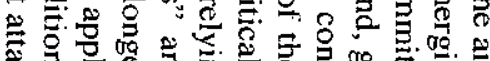

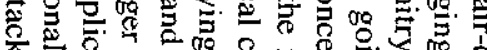

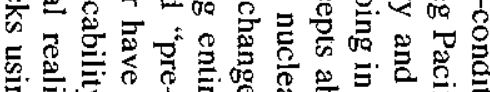

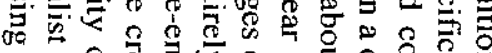

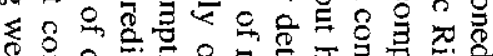

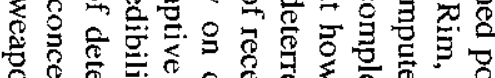

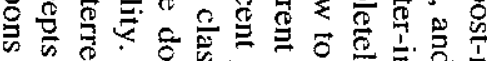

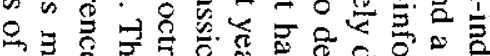

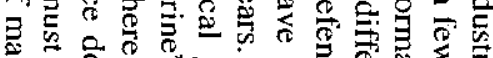
क्षे

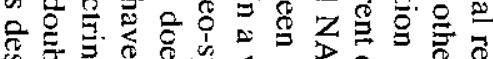

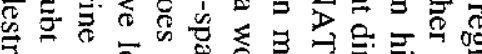

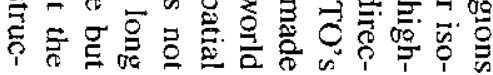




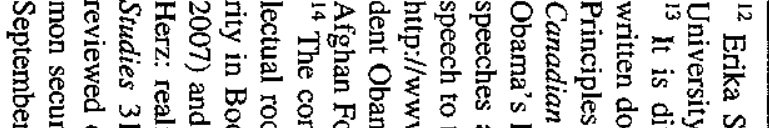

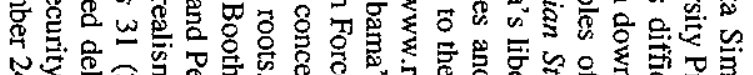

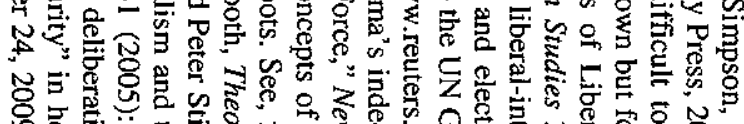

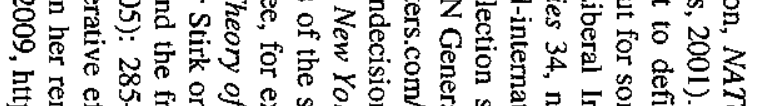

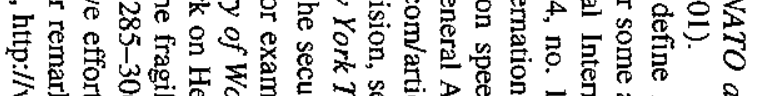

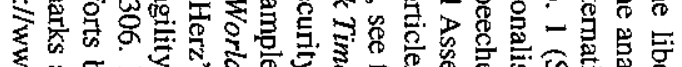

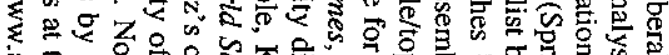

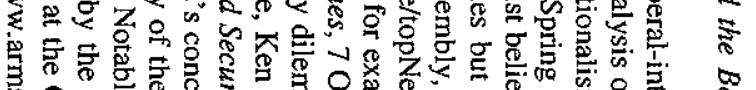

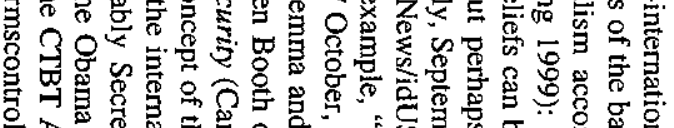

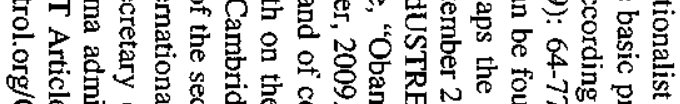

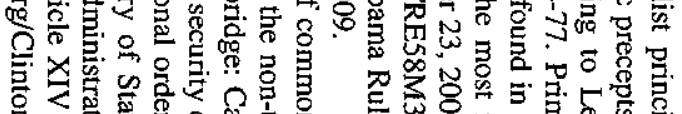

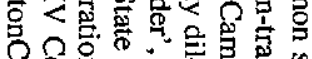

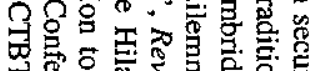

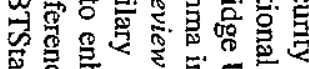

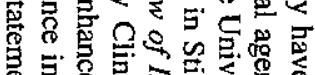

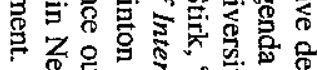

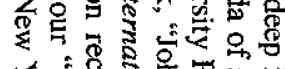

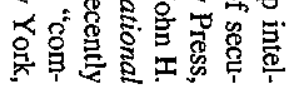

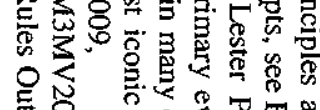

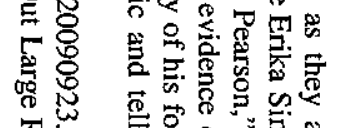

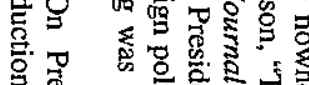

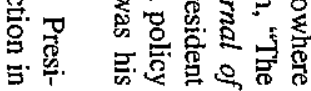

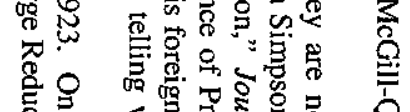

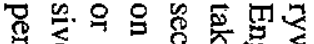

ชั ๙

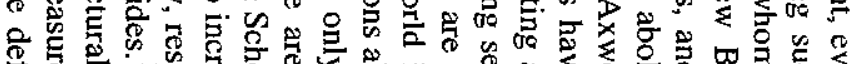
矛密

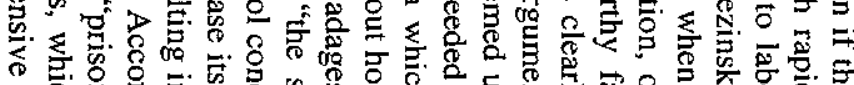

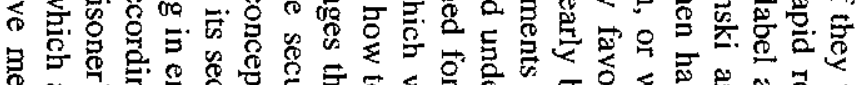

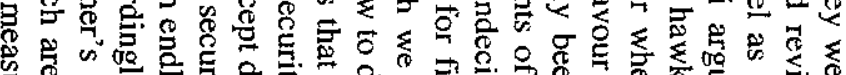

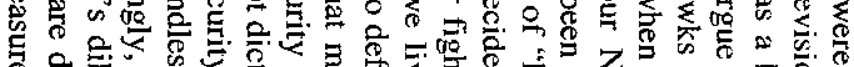

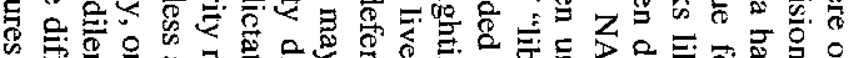

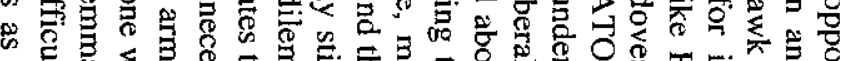

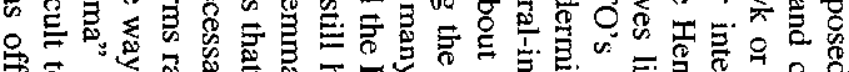

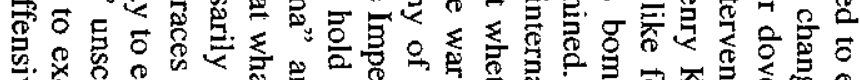

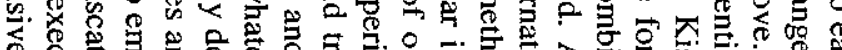

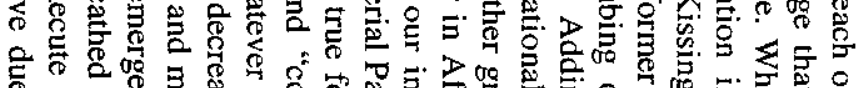

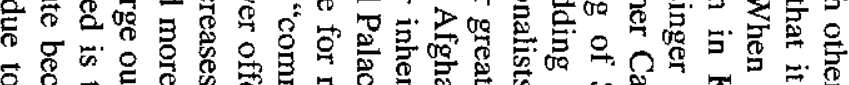

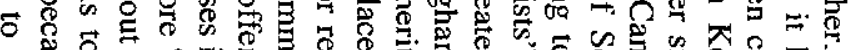

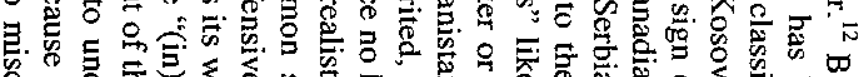

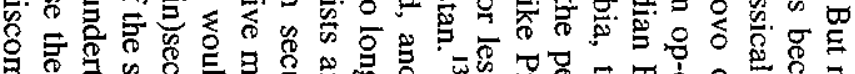

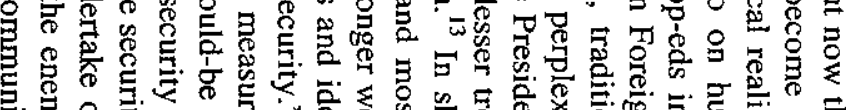

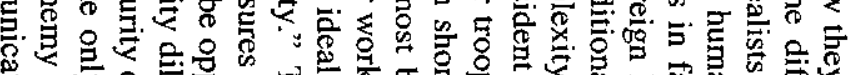

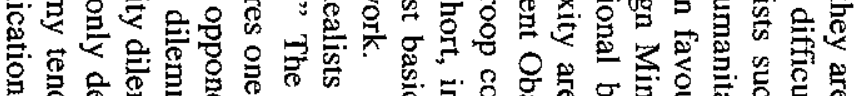

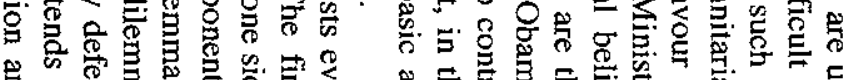

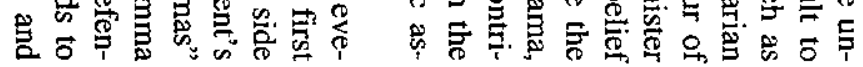

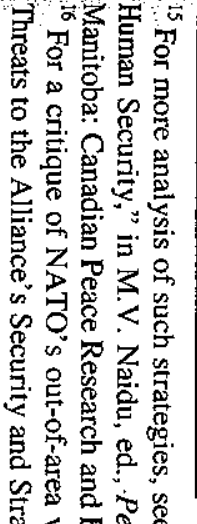

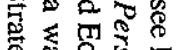

空.

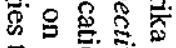

5 두용

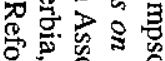

当裙.

$z \stackrel{0}{\circ}$

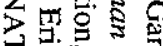

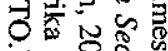

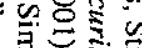

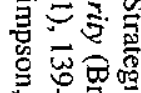

运要

蛋客言

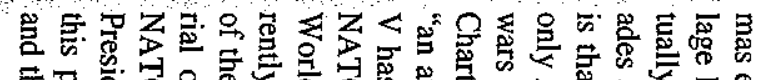

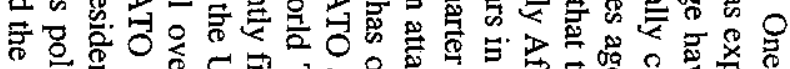

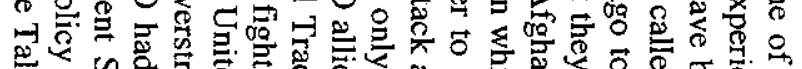

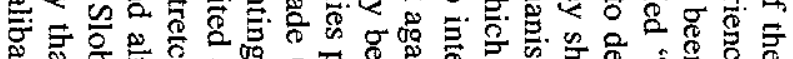

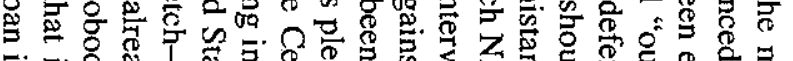

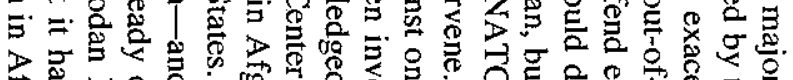

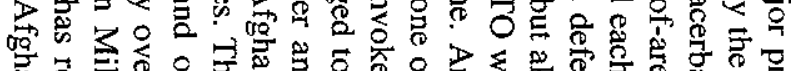

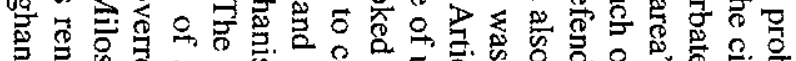
可 \%

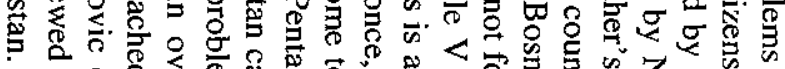

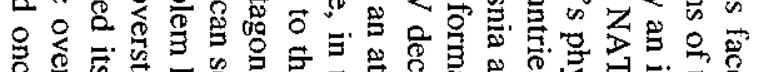

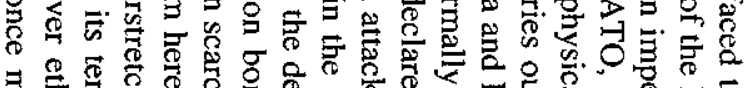

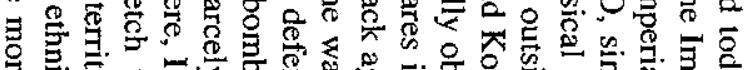

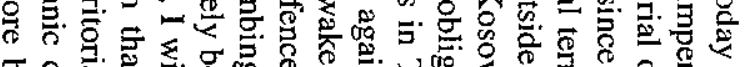

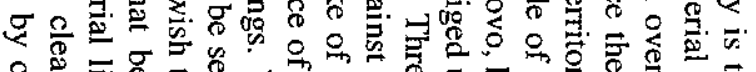

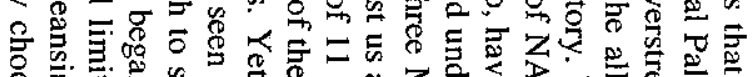

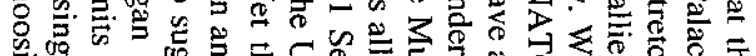

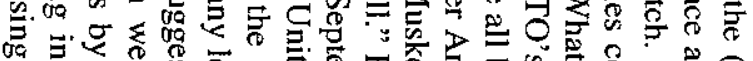

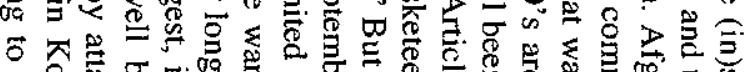

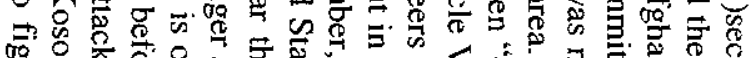

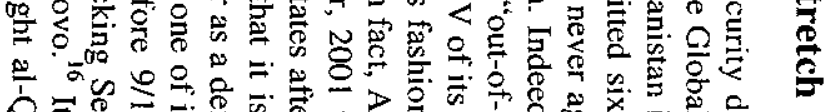

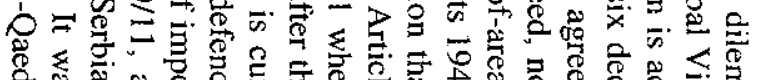

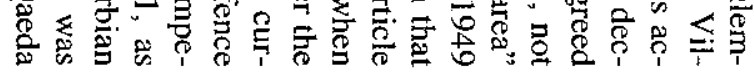

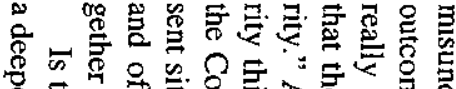

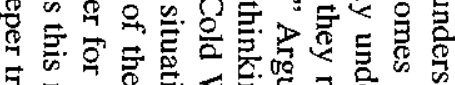

志矛富

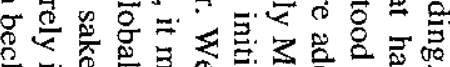

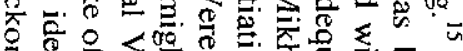

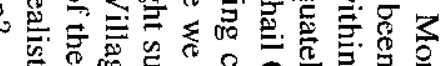
.

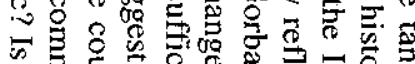

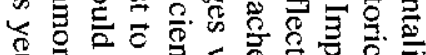

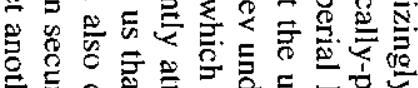

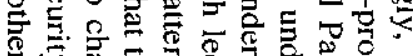

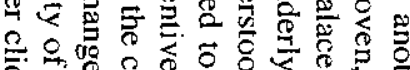

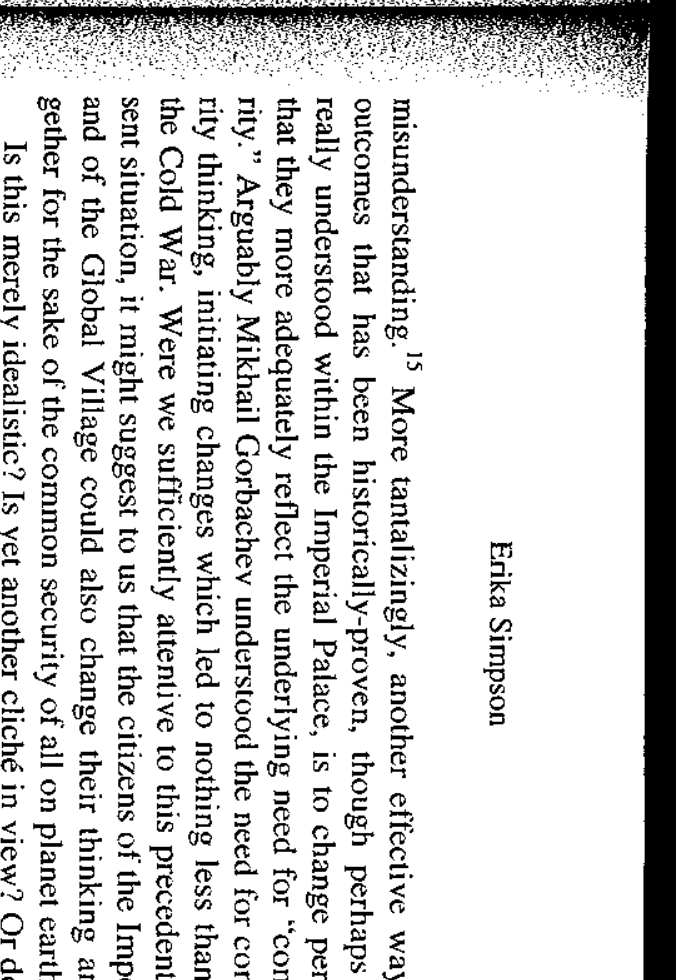

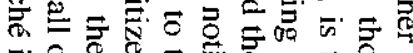

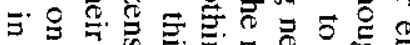

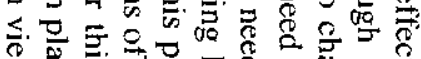

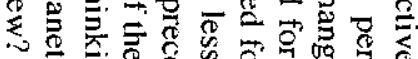
०र

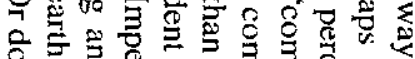

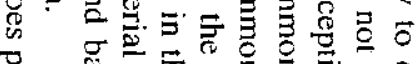

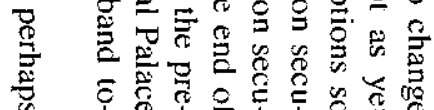




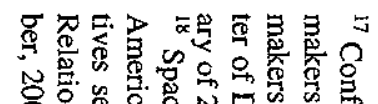

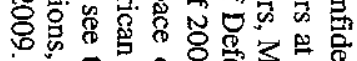

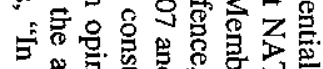

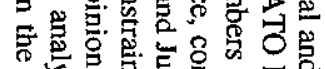

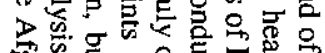

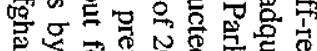
$5<$ 웅

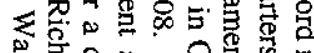
牙 \&

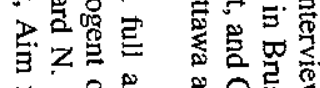

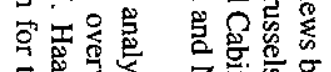

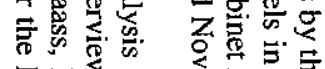

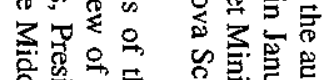

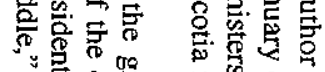

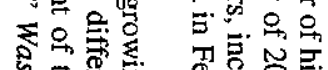

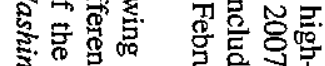

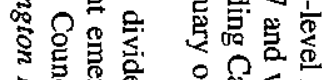
大

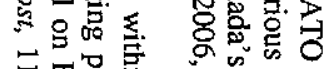

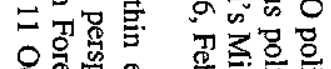

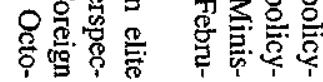

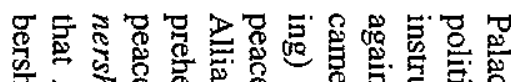

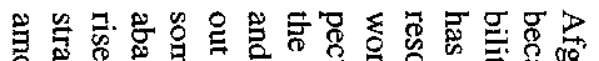

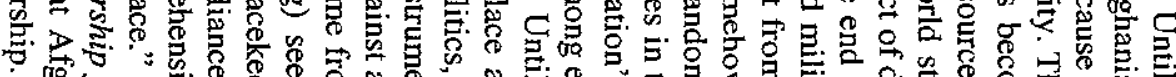

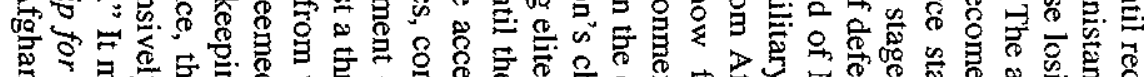

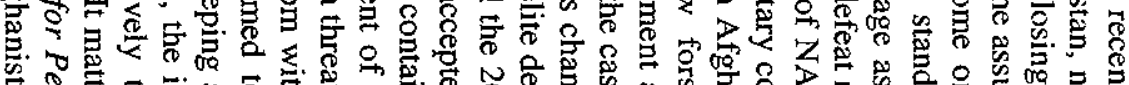

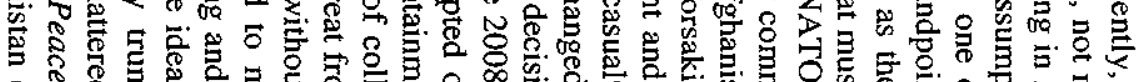

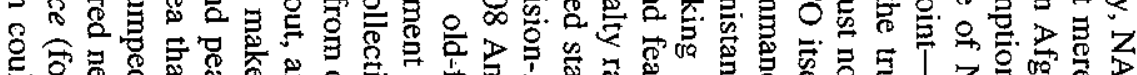

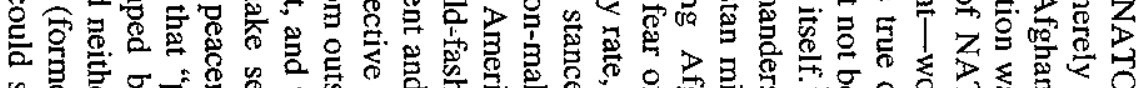

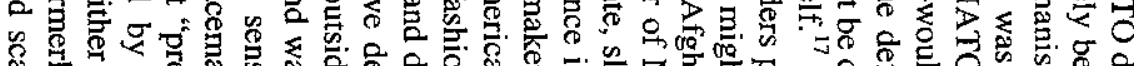

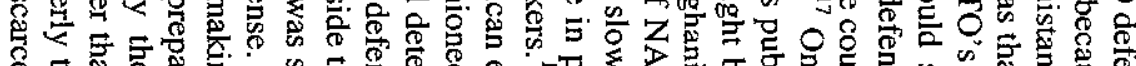

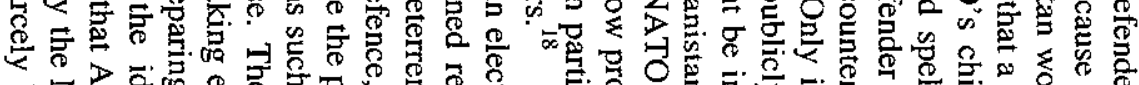

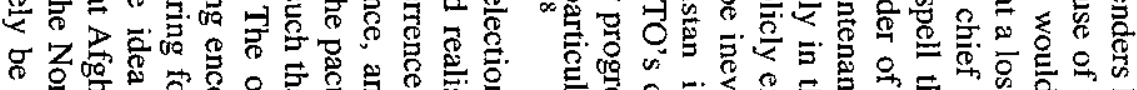

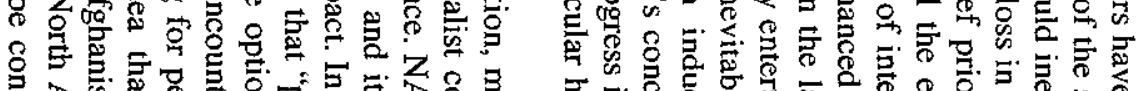

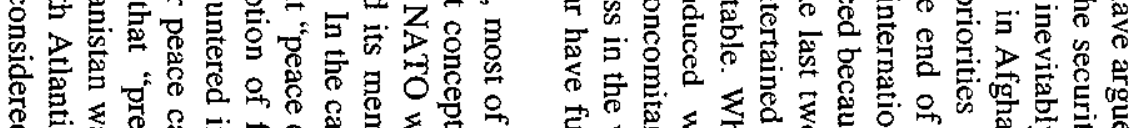

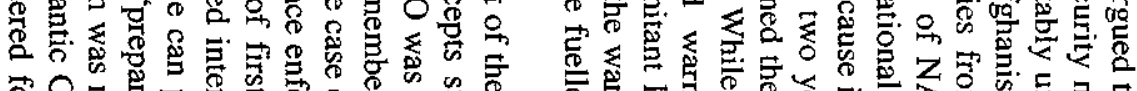

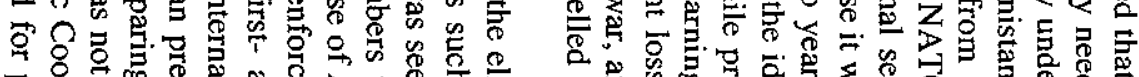

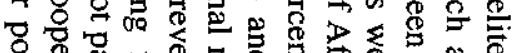

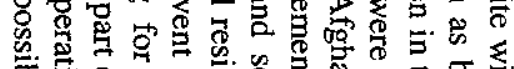

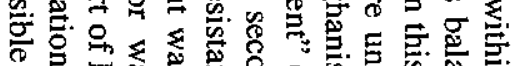

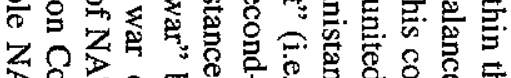

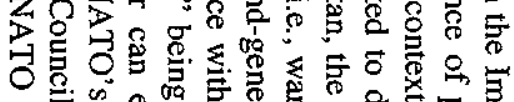

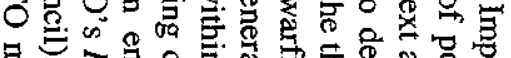

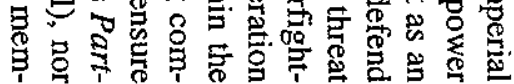

$\overleftrightarrow{\infty}$

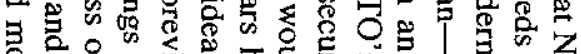

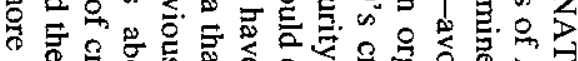

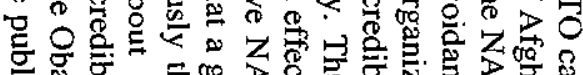

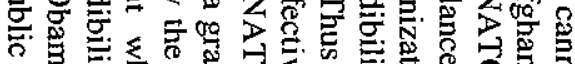

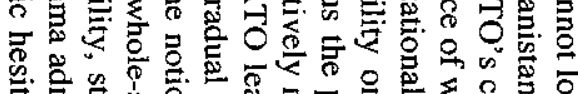

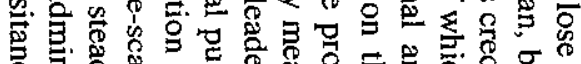

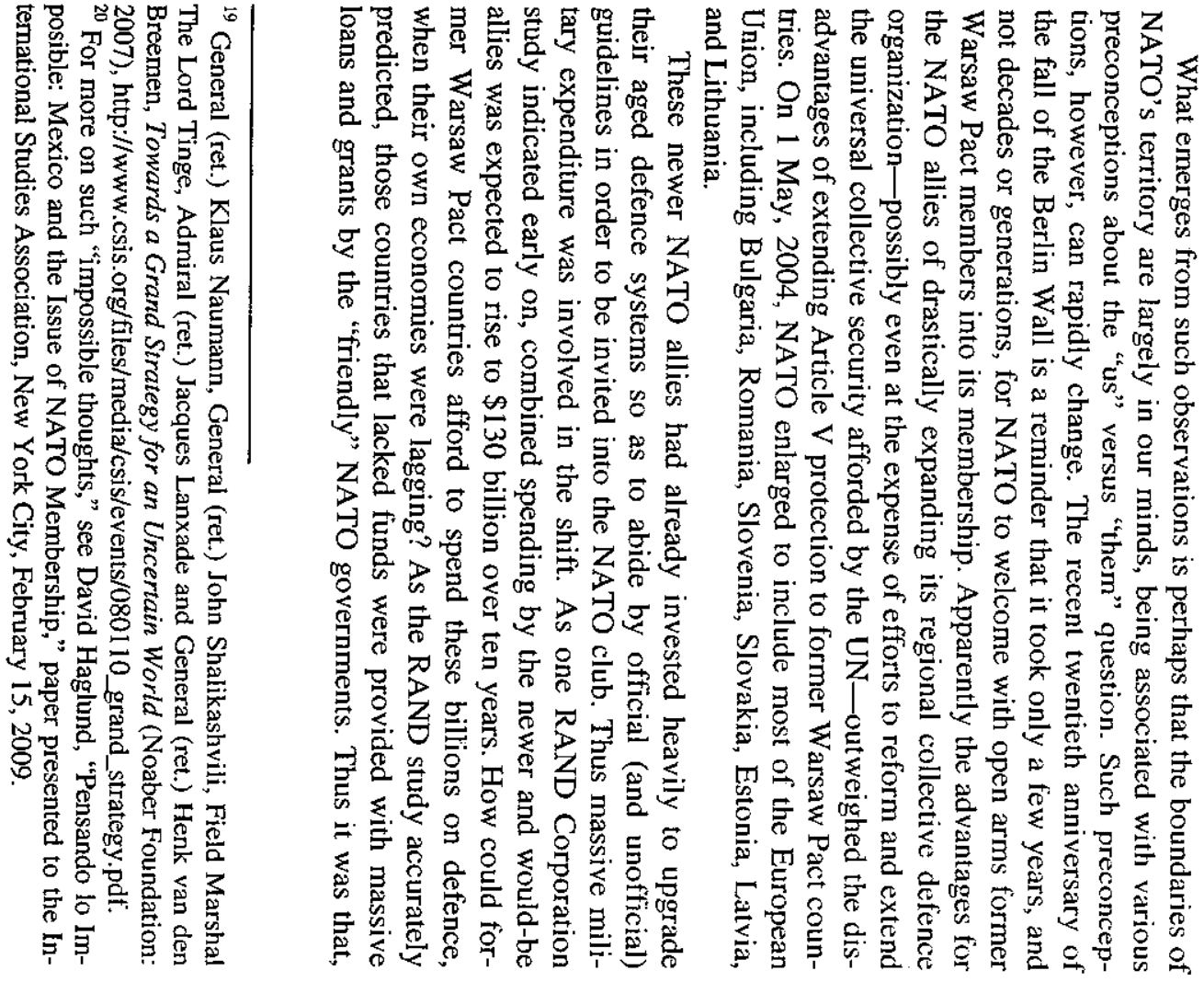

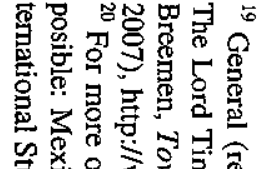

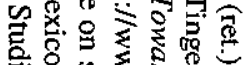

की

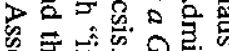

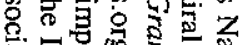

爱.

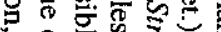

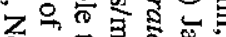

₹

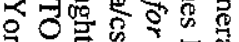

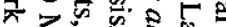

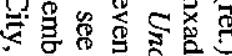

T工力

政.

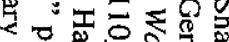

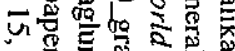

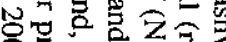

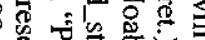

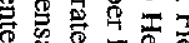

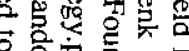

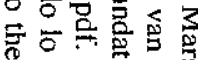

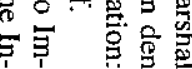

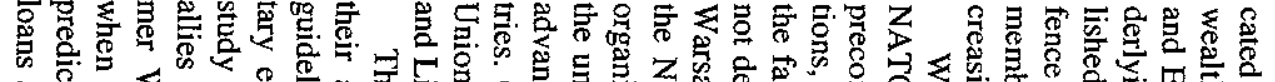

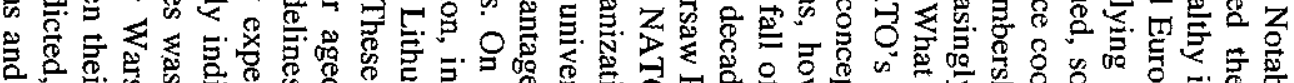

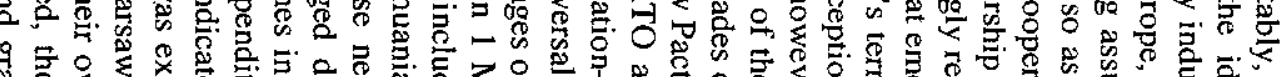

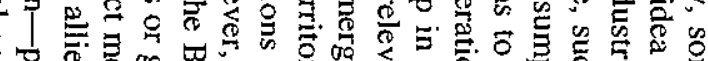

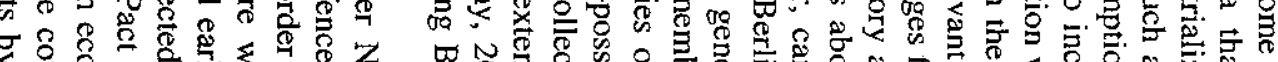

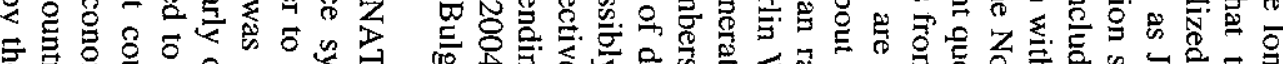

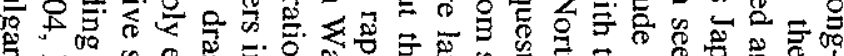

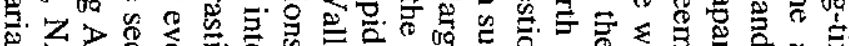

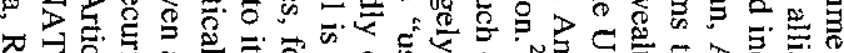

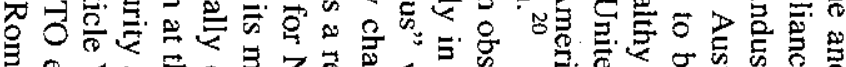

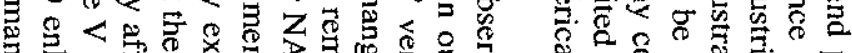

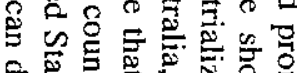

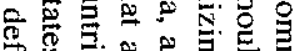

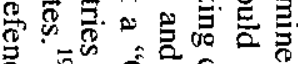

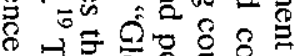

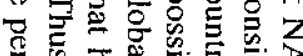

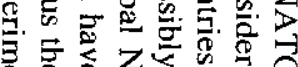
कृत

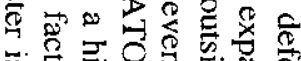

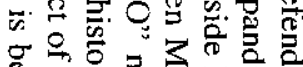

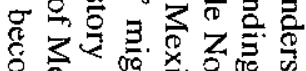

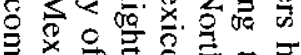

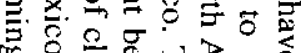

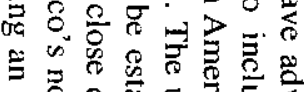

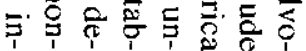

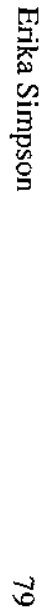




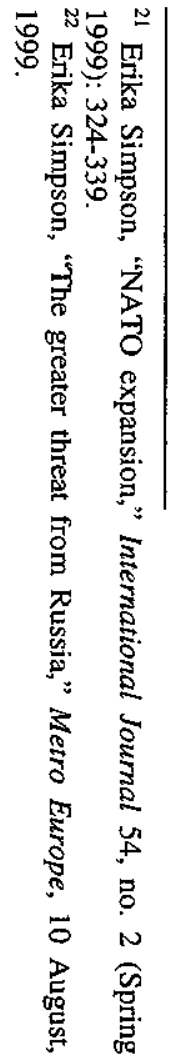

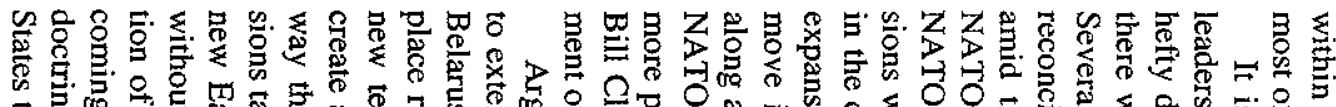

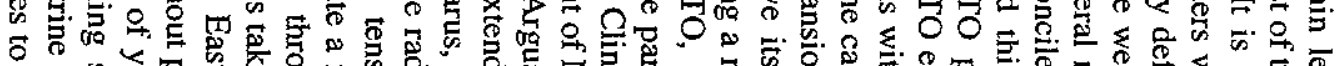

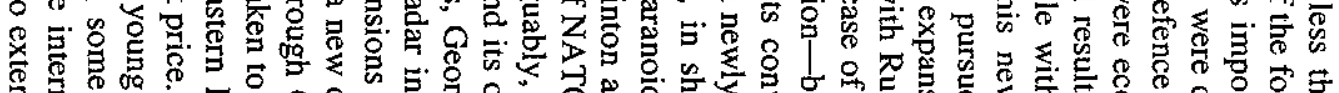

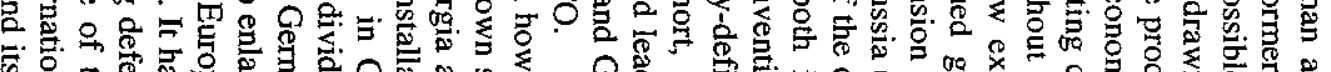

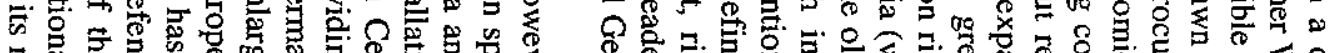

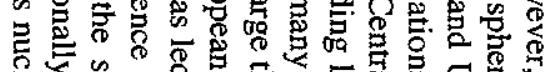

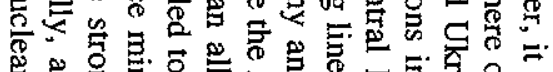

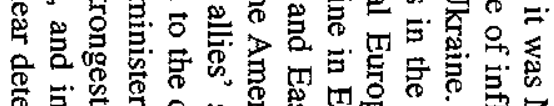

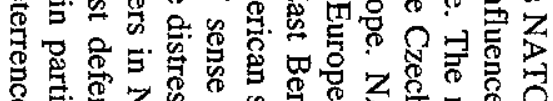

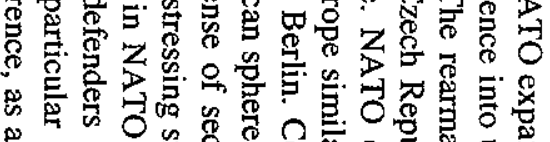

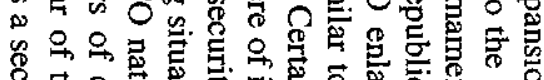

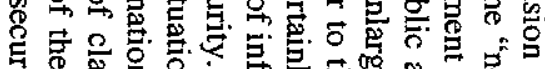

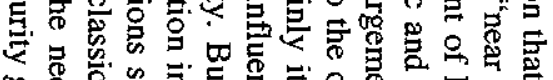

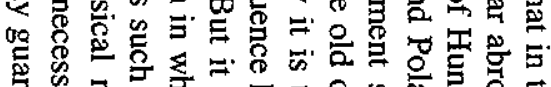

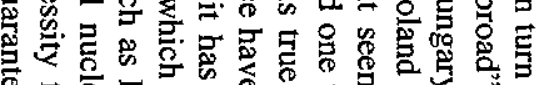

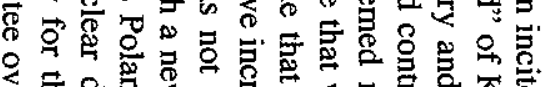

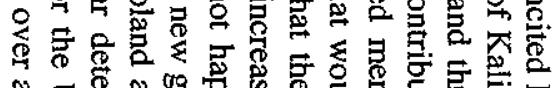

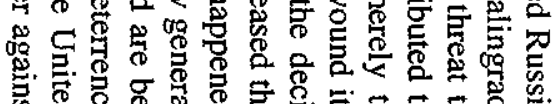

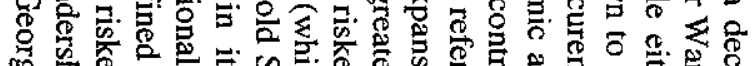

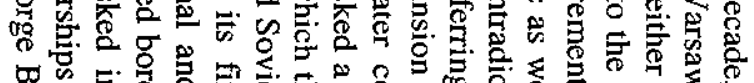

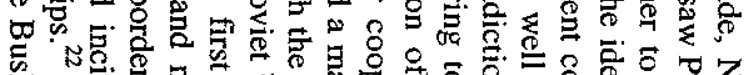

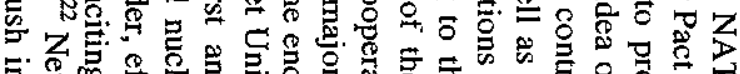

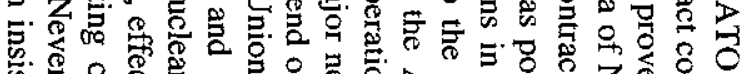

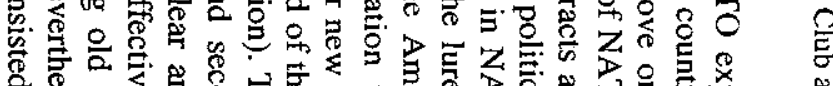

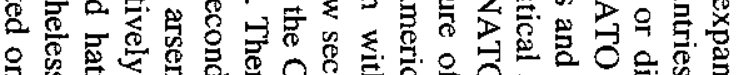

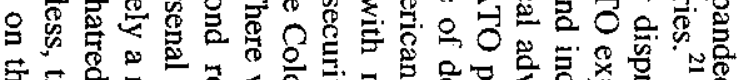

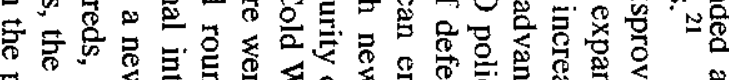

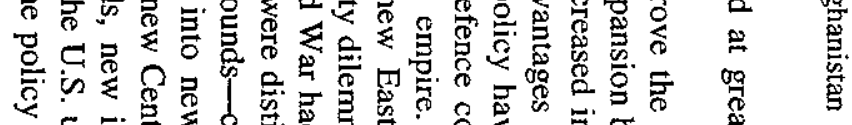

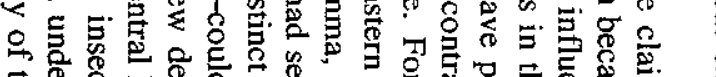

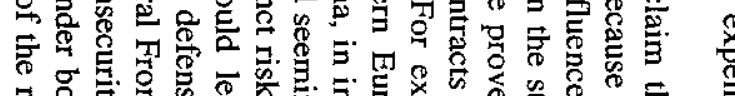

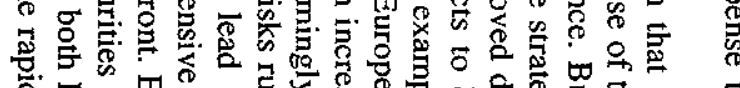

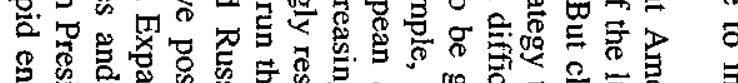

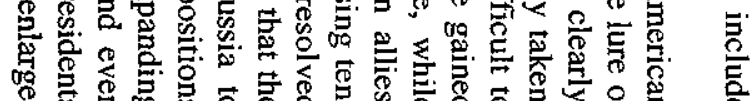

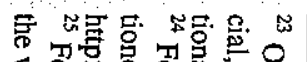

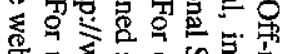

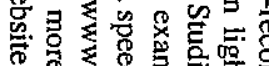

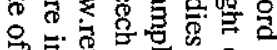

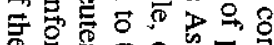

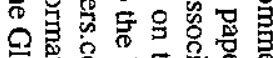

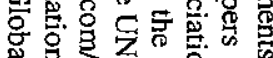

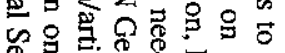

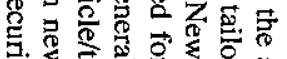

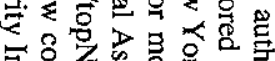

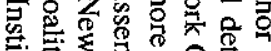

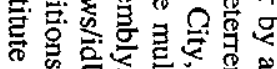

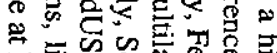

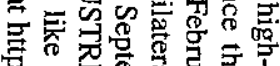

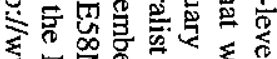

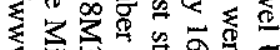
₹

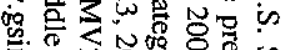

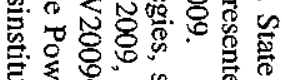

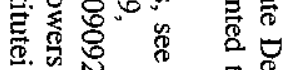

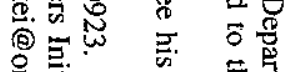

$\stackrel{\circ}{00}$

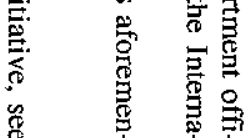

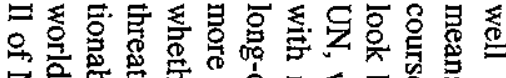

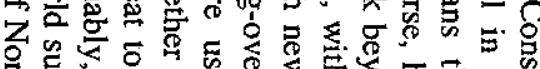

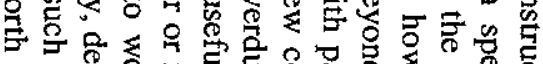

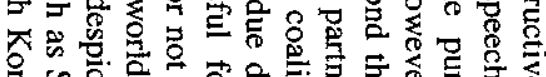

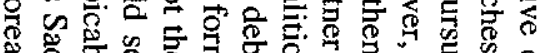

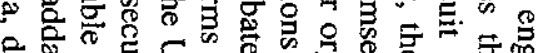

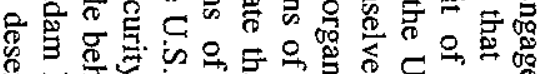

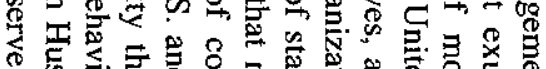
๙

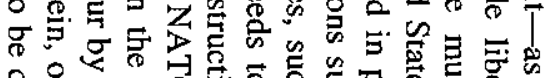

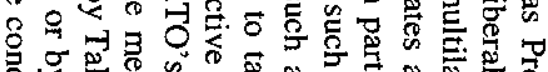

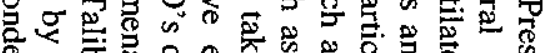

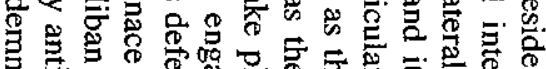

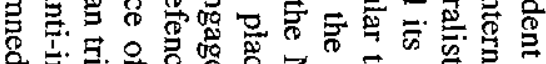

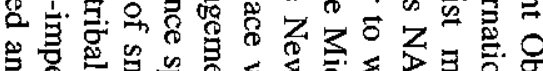

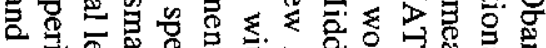

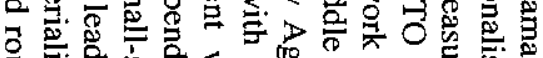

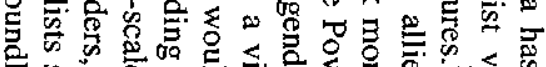

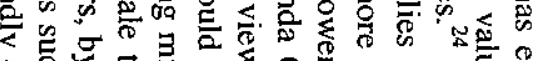

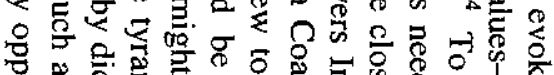
क

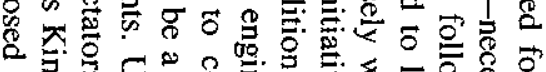

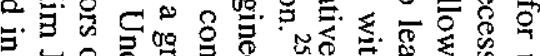

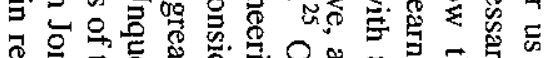

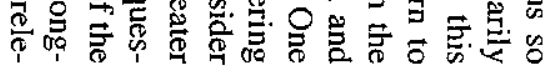

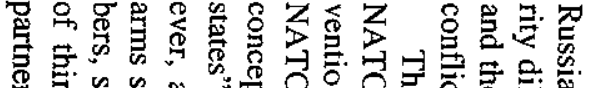

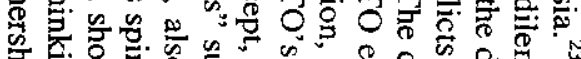

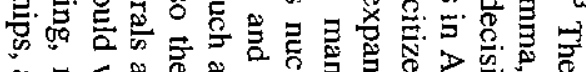

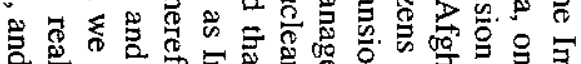

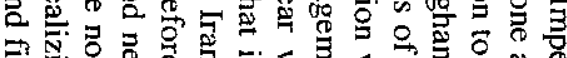

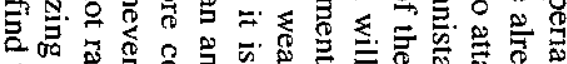

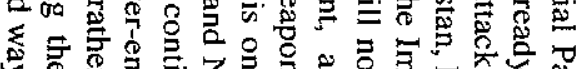

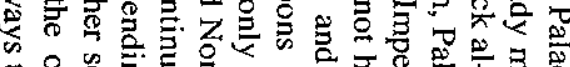

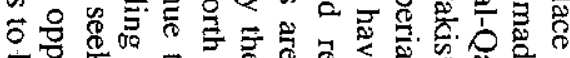

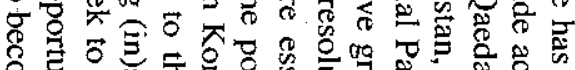

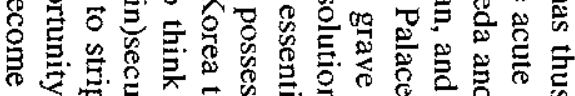

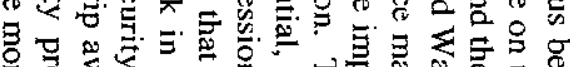

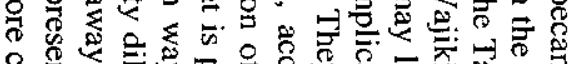

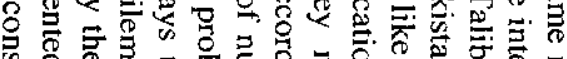

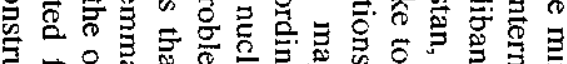

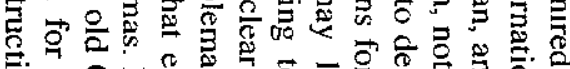

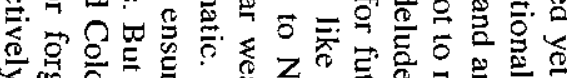

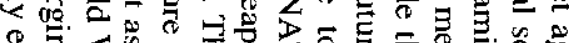

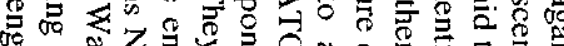

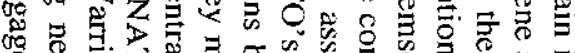

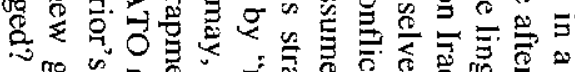

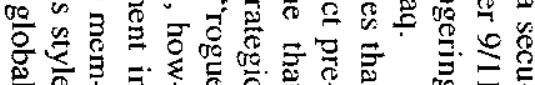

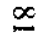




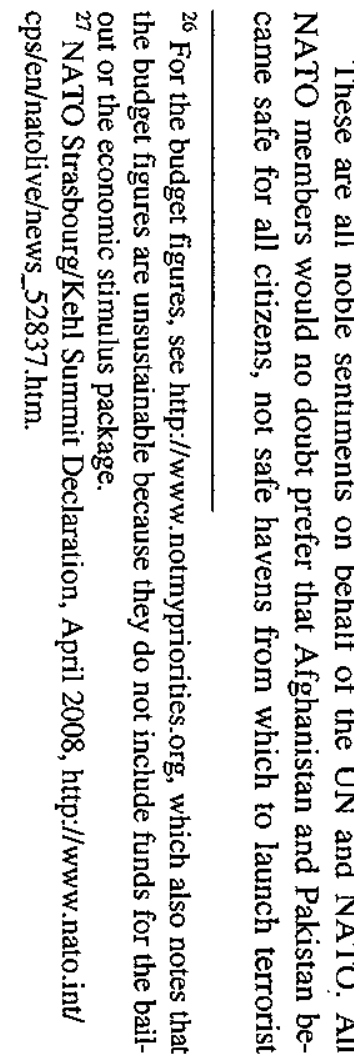

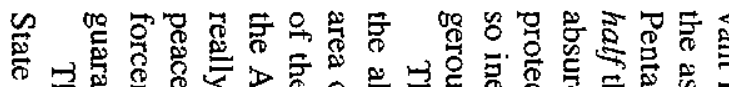
悉

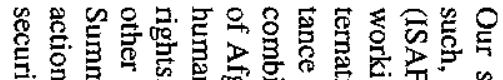

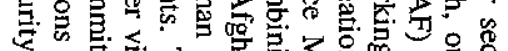

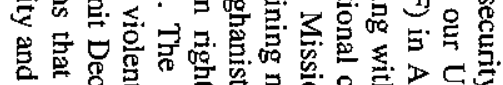

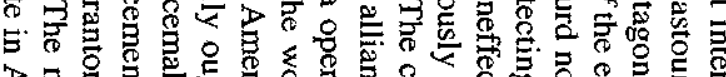

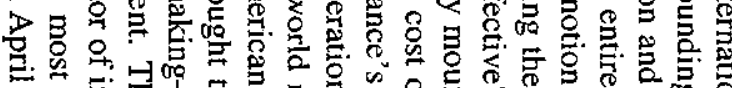

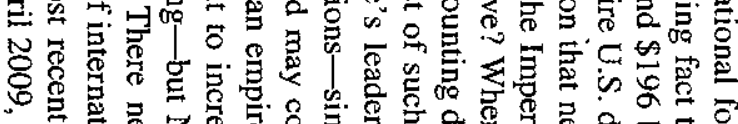

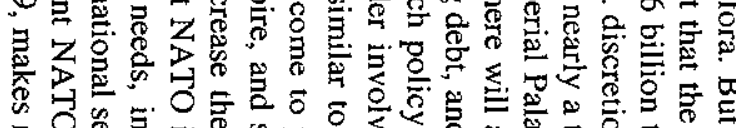
3 O०

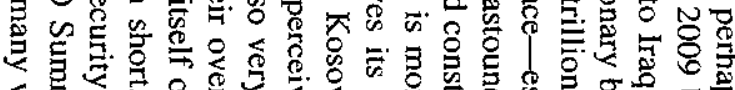

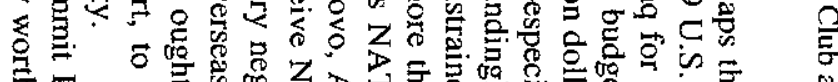

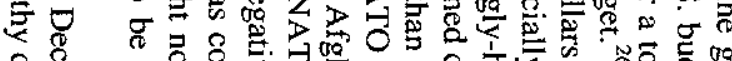
용

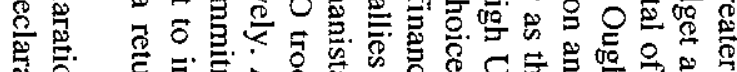

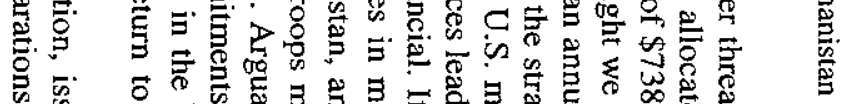

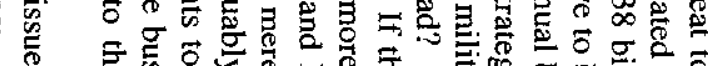

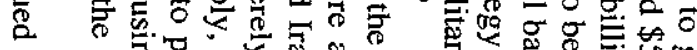

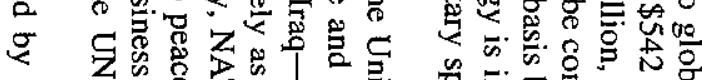

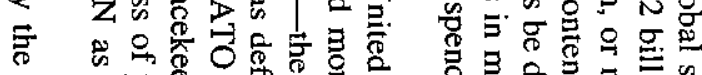

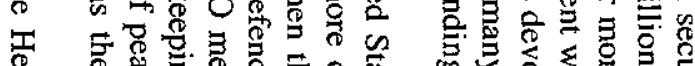

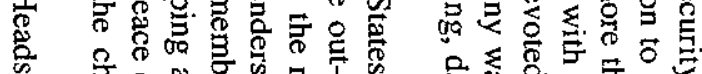

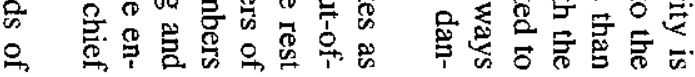

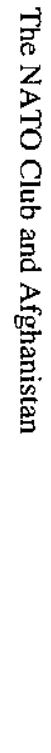

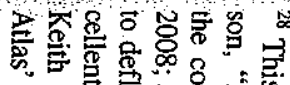

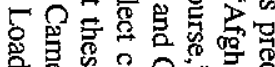

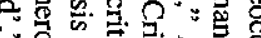

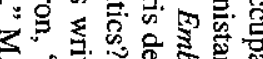

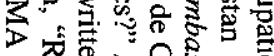

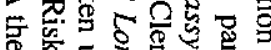
象 с

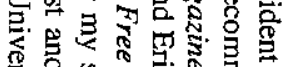

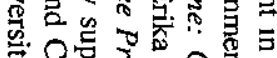

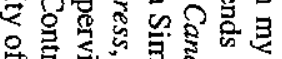
虽家象要

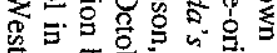

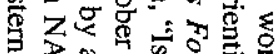

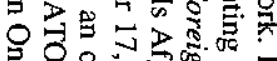

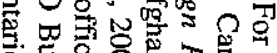
응

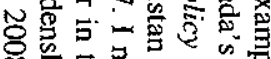

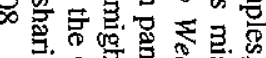
高 完 을

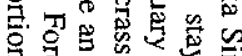

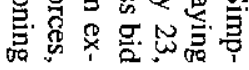

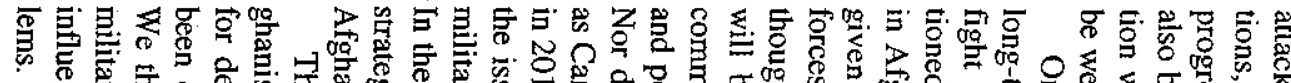

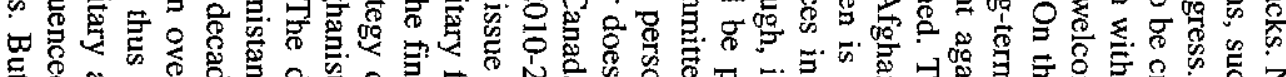

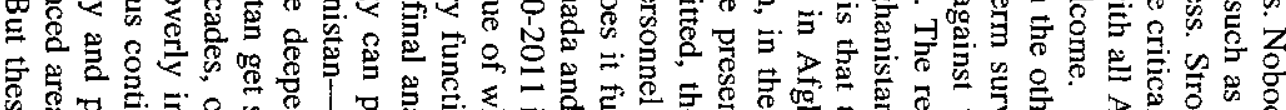

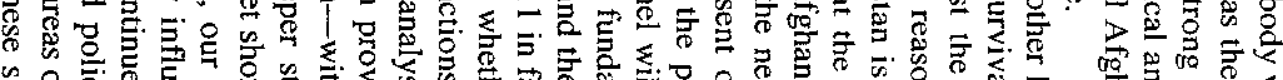

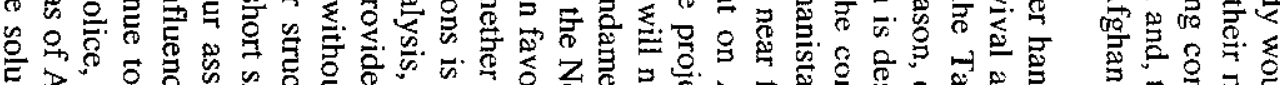

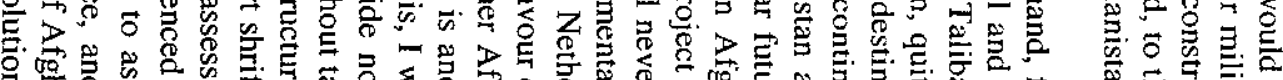

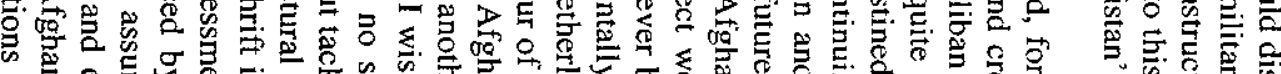

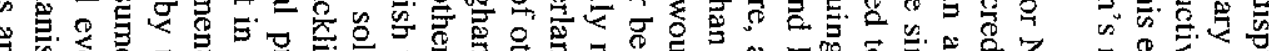

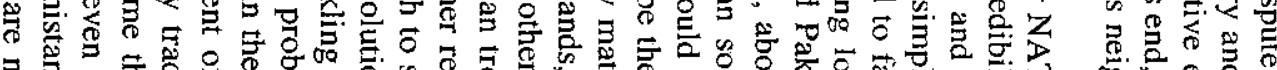

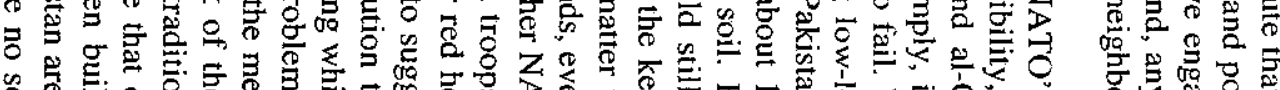

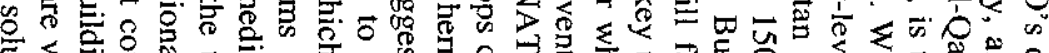

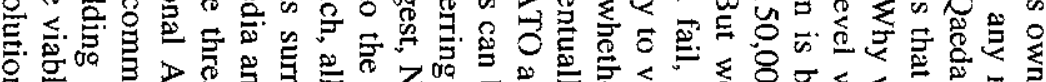

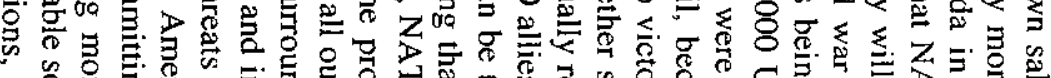

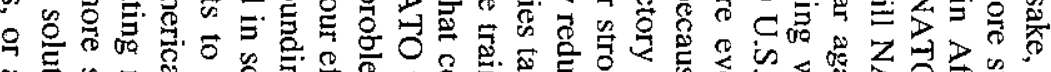

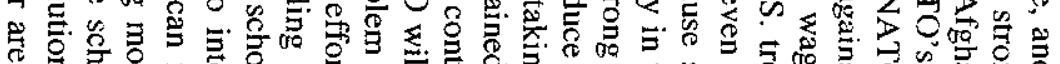

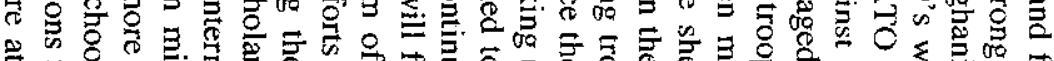

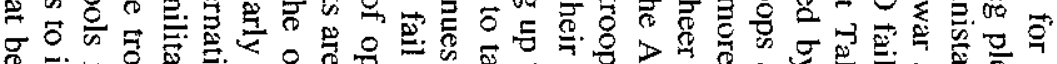

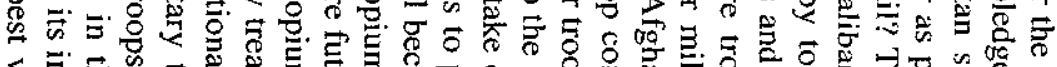

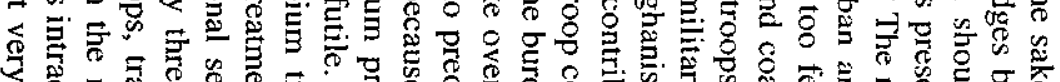

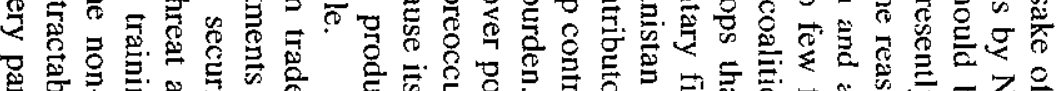

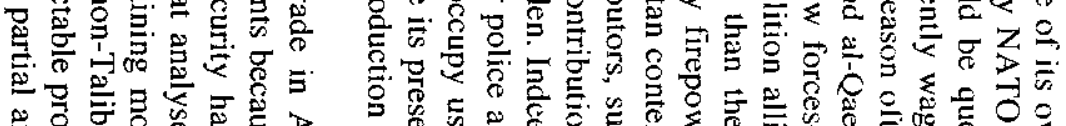

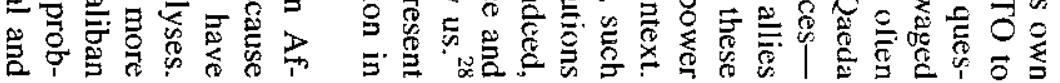

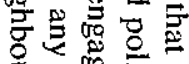

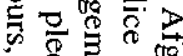
8 造密

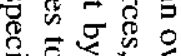

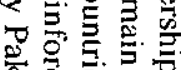
हैं 0

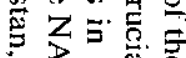
告家

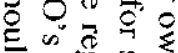
숭. 造高

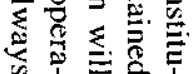
要.

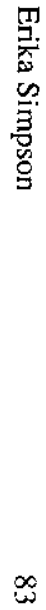




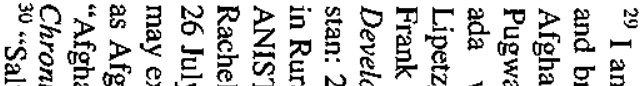

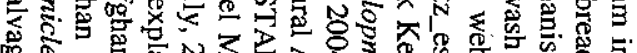

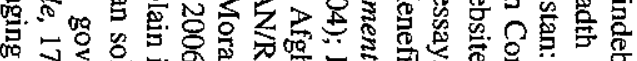

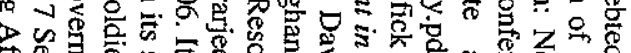

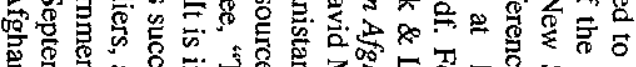

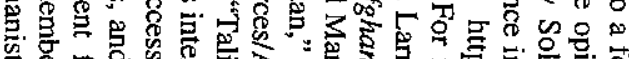

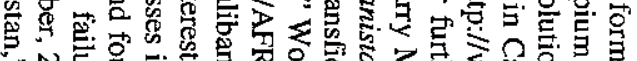

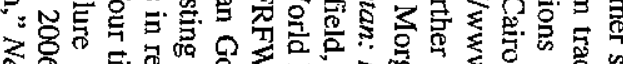
₹

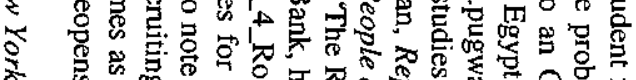

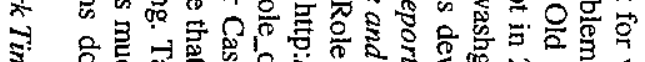

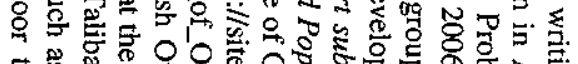

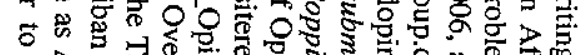

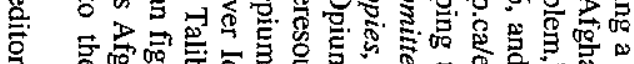

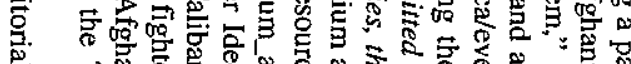

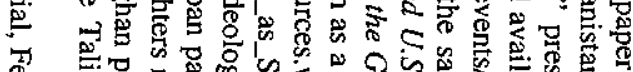

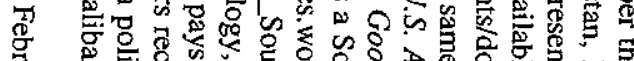

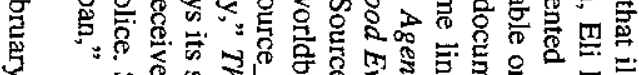

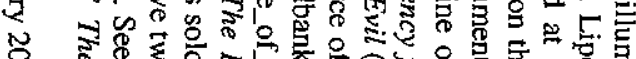

和

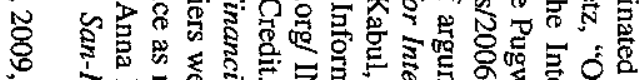

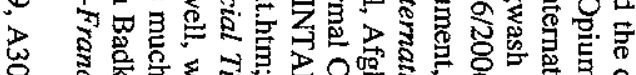

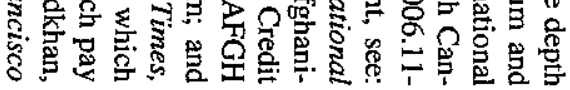

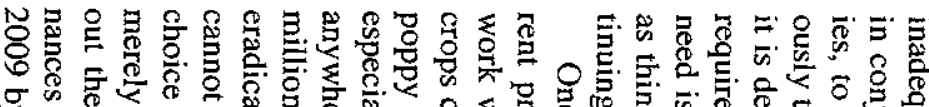

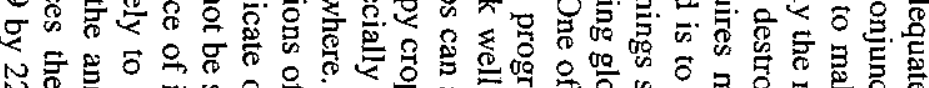

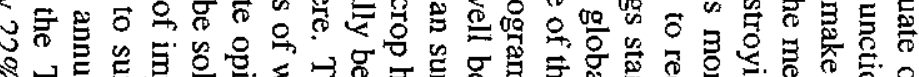

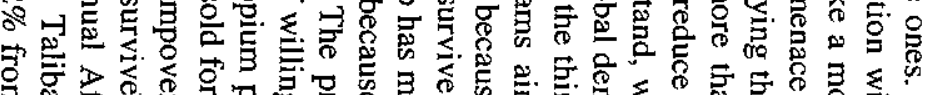

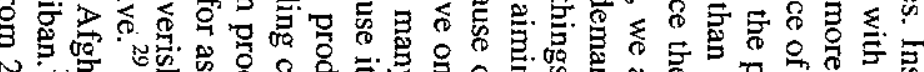

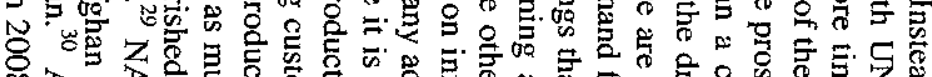

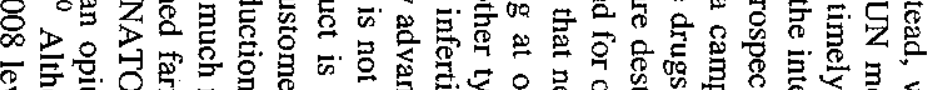

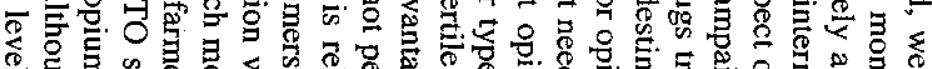

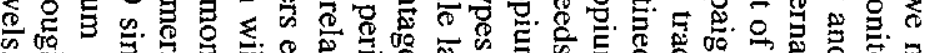

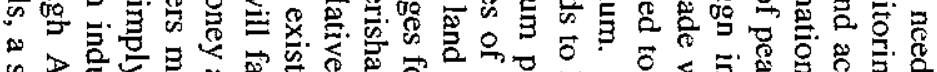

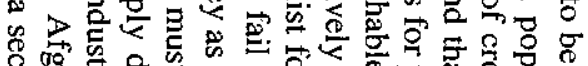

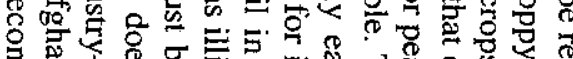

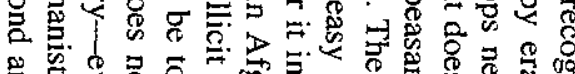

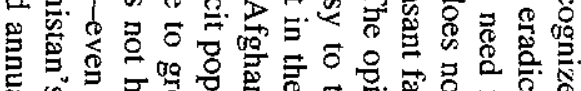

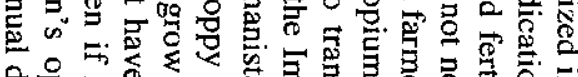

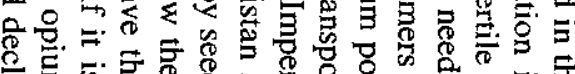

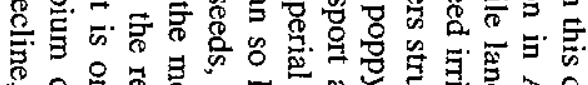

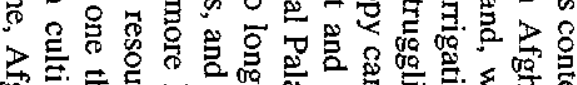

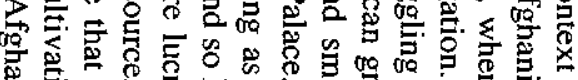
ㄱ. 을

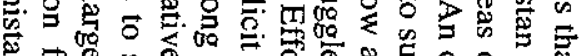

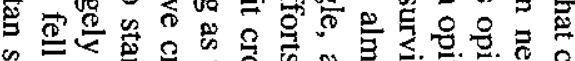

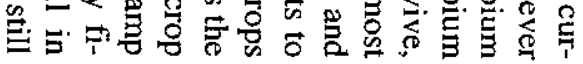

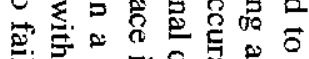

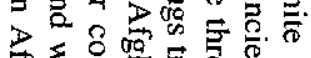

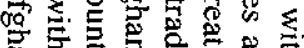

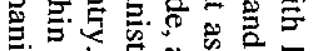

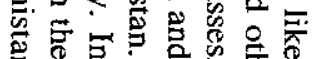

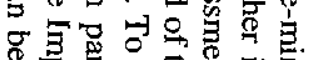

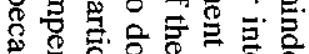

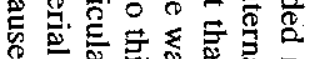

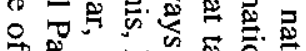

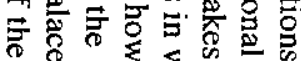

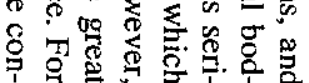

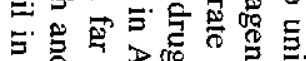

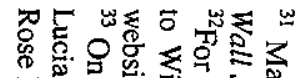
叹

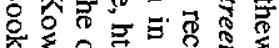

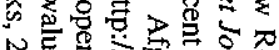

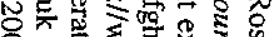

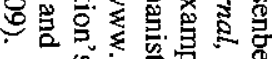

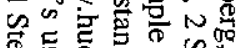

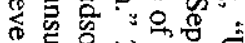

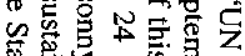

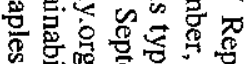

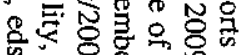
\& 8 \% $\rightarrow$ 过

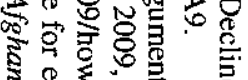

s.

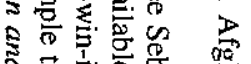

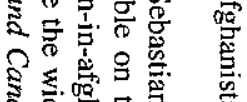

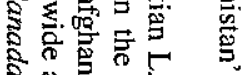

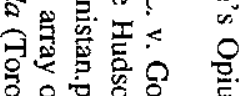

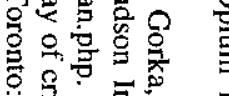

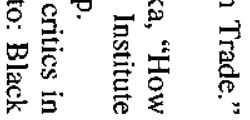

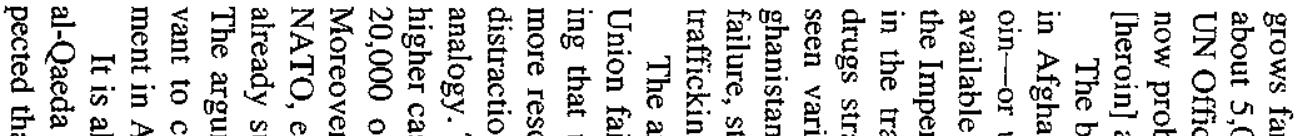

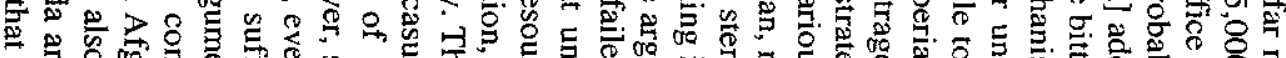

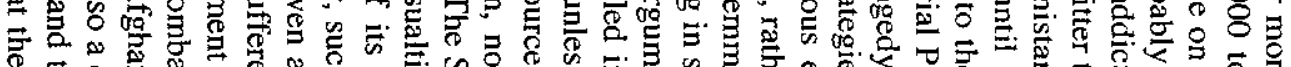
궁

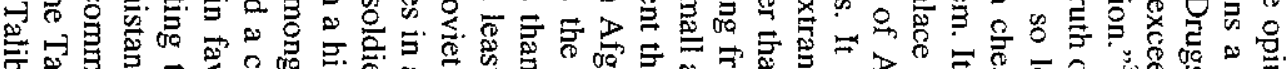

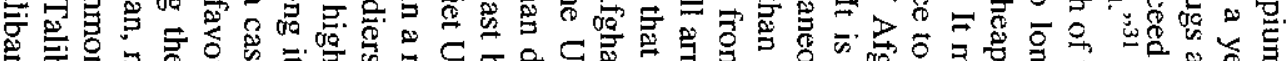
$\exists \vec{g}$

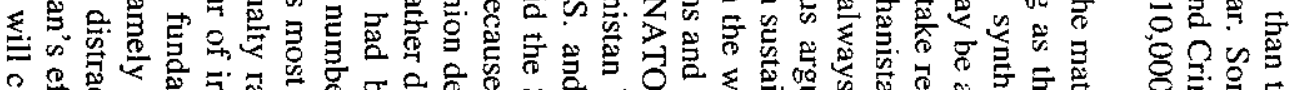

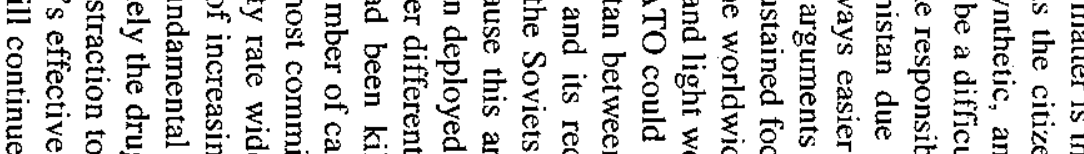

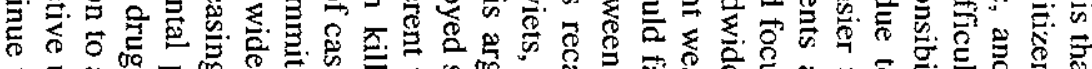
के

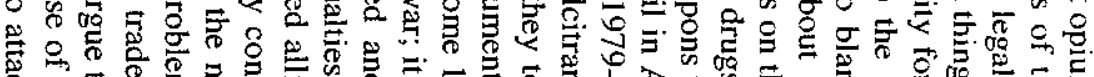

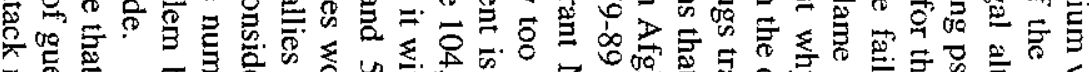

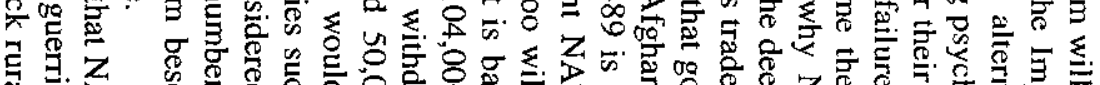

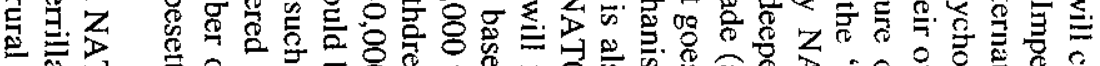

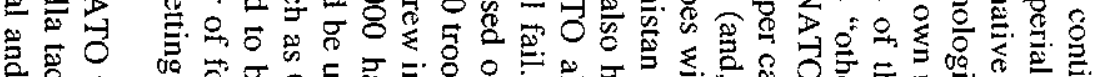

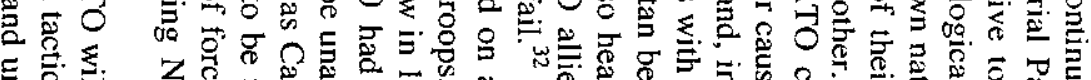

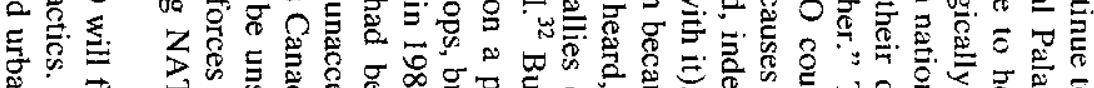

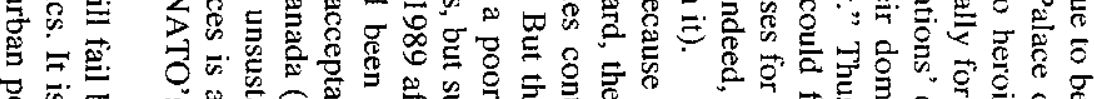

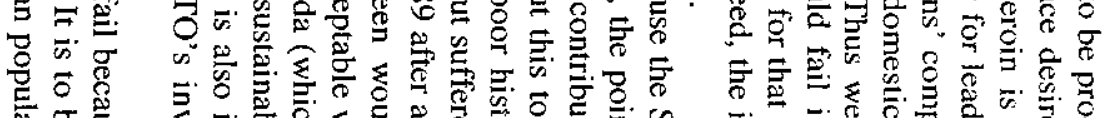

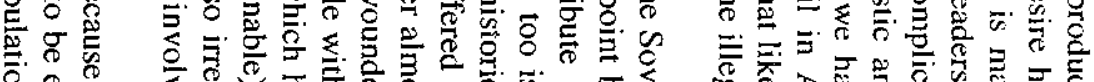

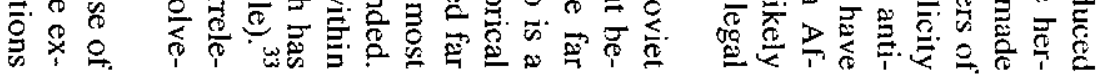
这的吉

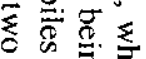
$\overleftarrow{8}$

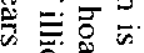

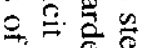
$\xi \frac{\mathrm{O}}{2}$ 言灾宫

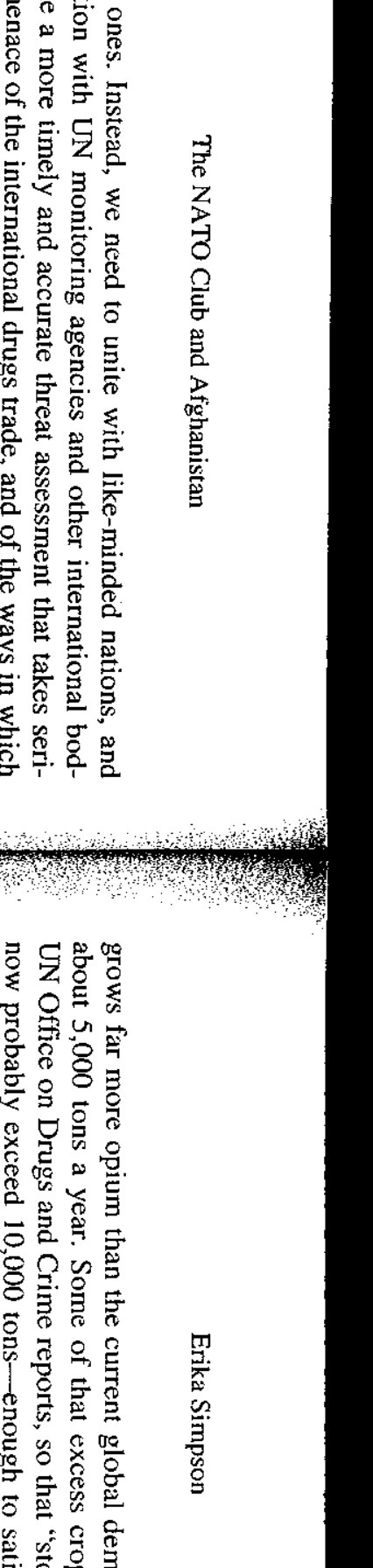

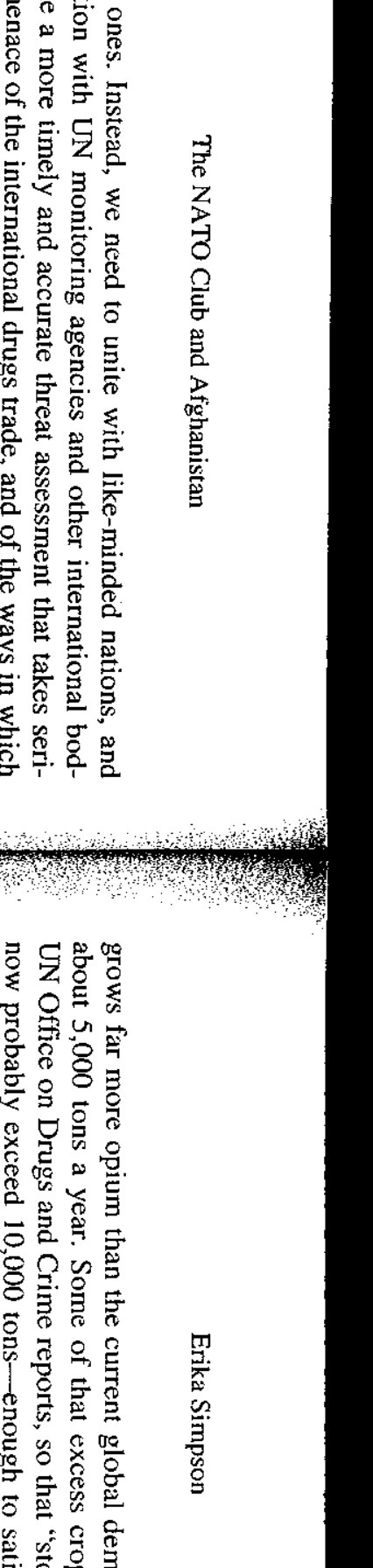

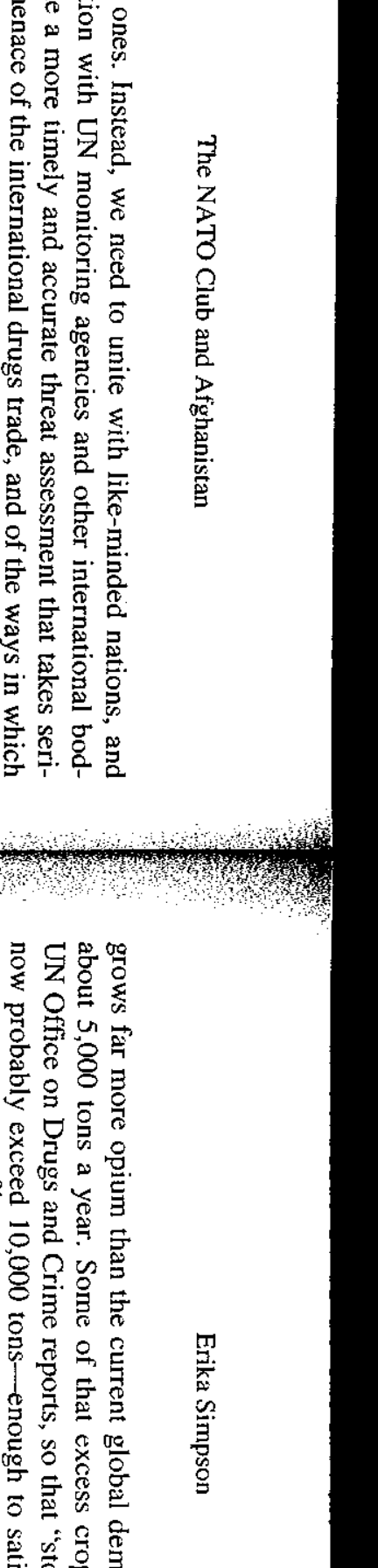

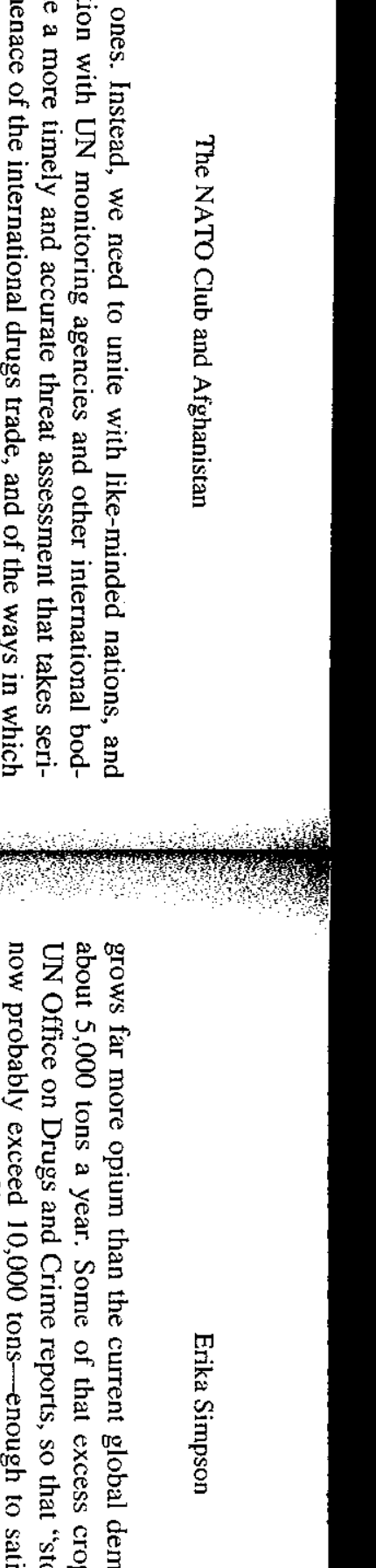

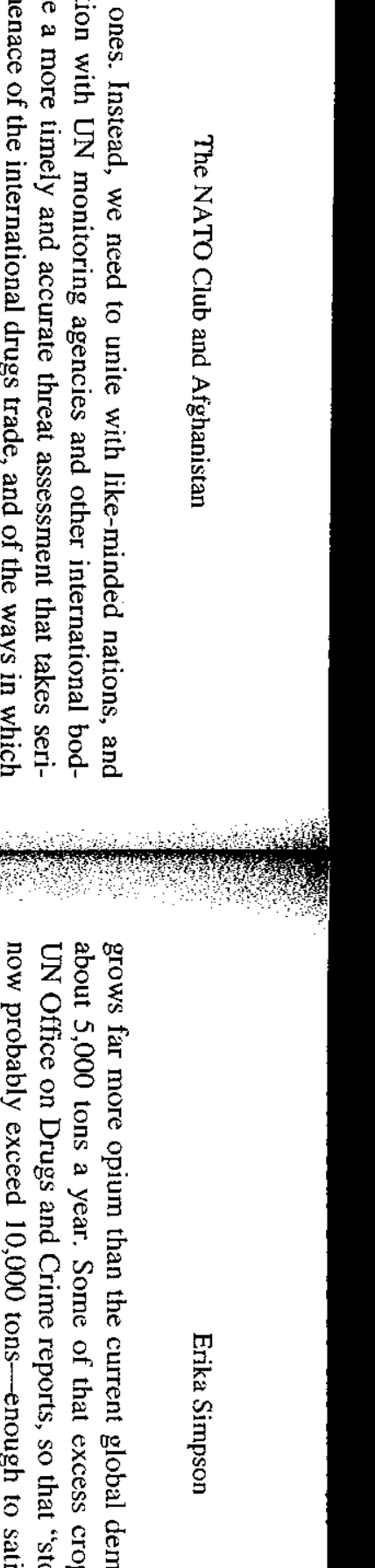




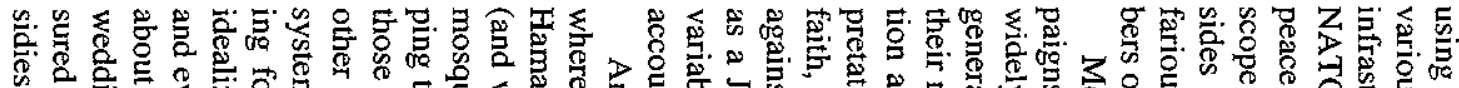

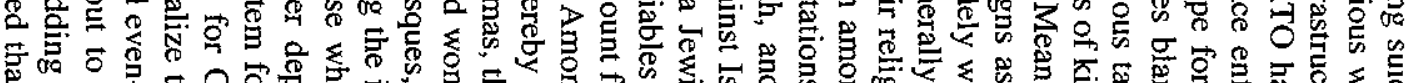

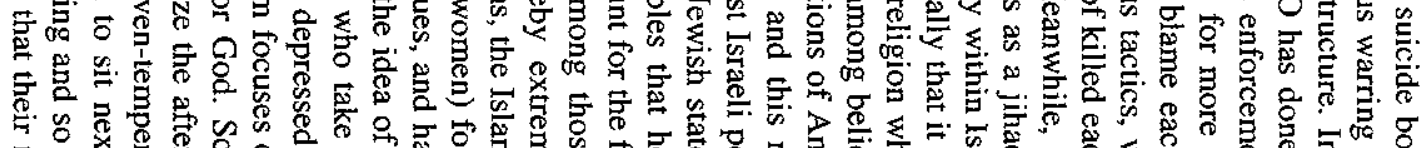

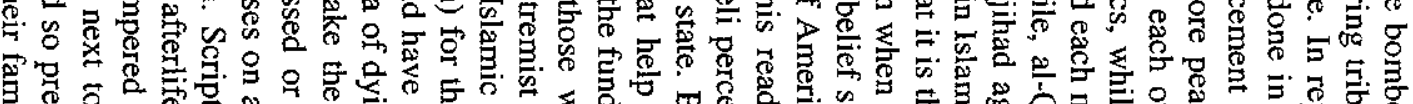

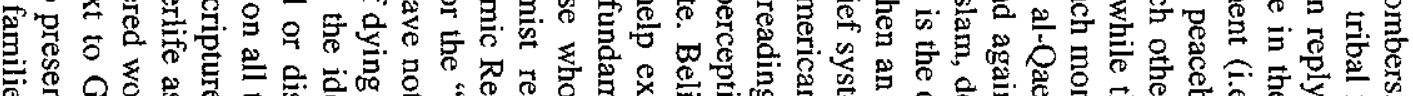

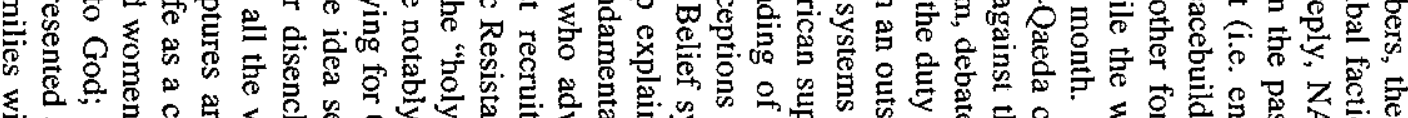

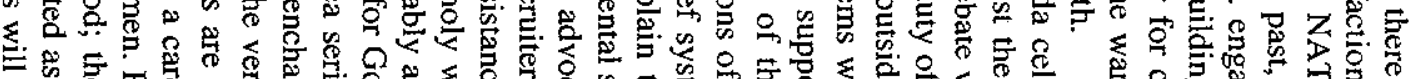

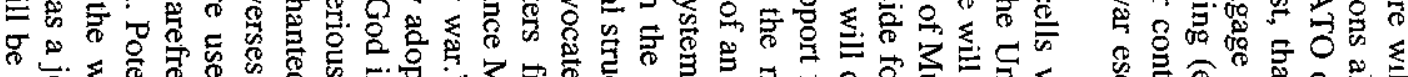

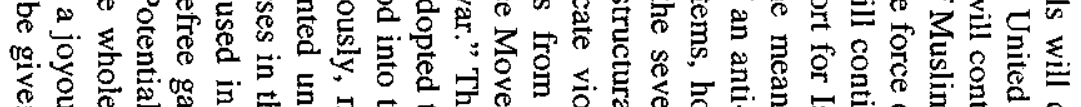

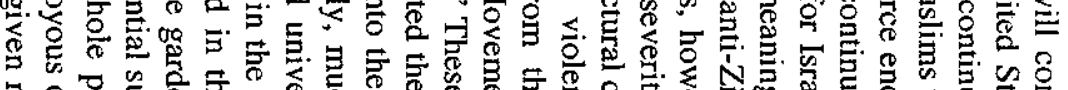

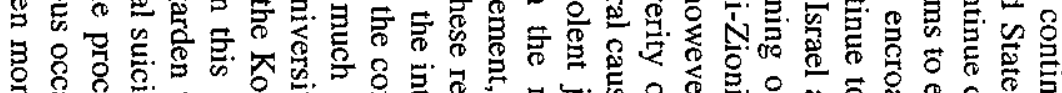

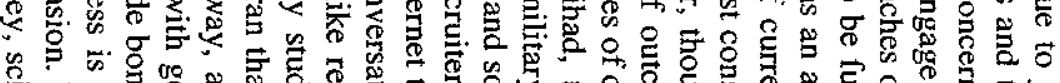

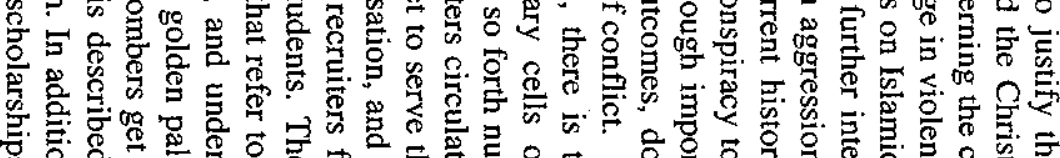

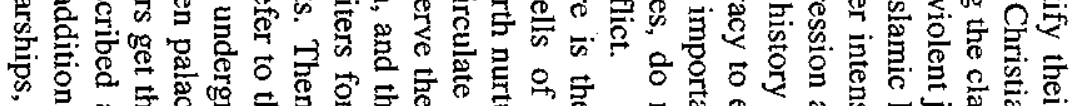

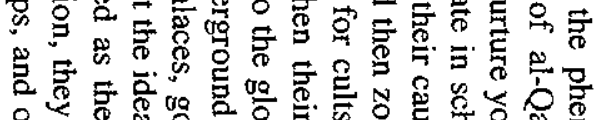

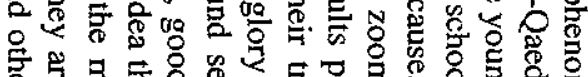

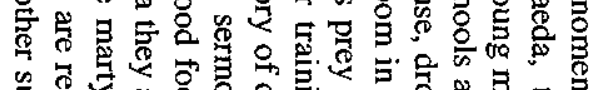
焉要

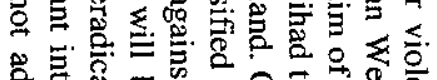

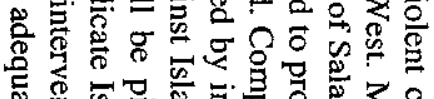

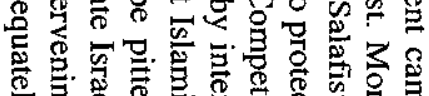

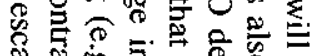

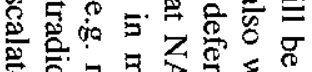

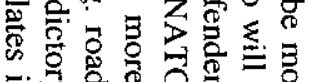
马.9

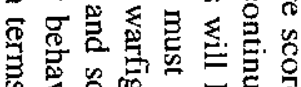

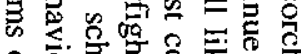

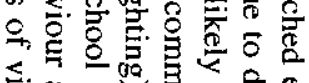

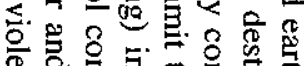

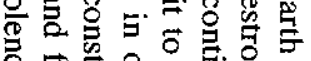

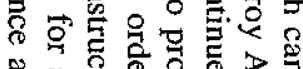

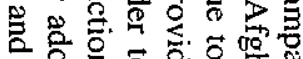

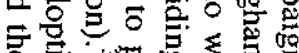

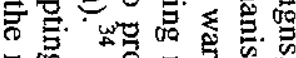

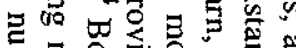

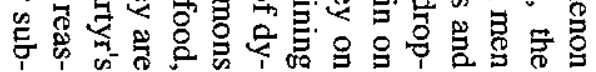

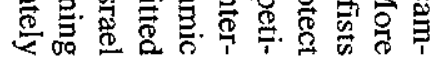

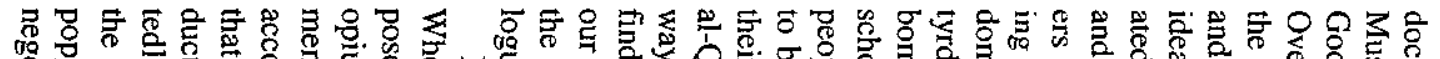

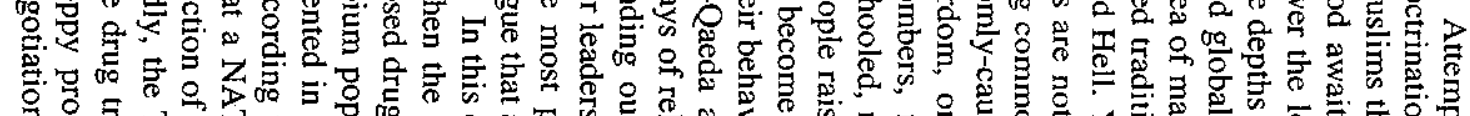

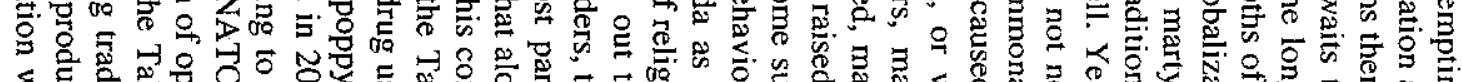

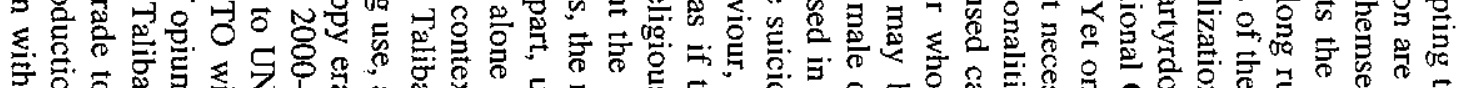
응 옹 蒫 奠

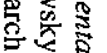

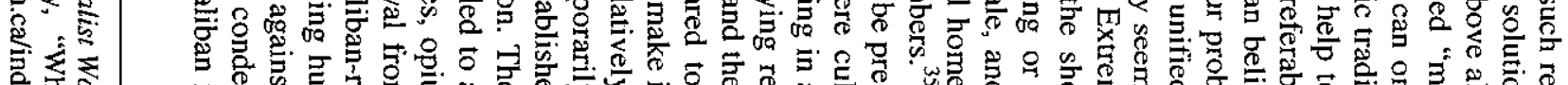

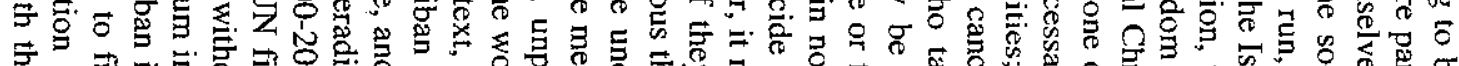

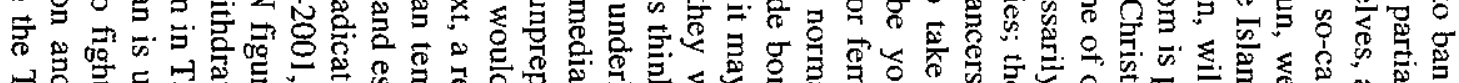

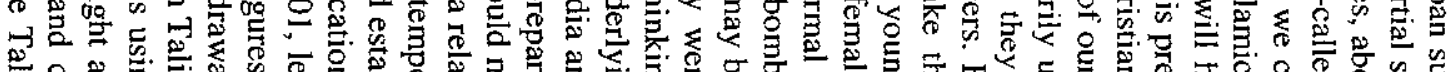
웡혀 㻤要官 㟒急哭 iï 8 突 $\prod_{i} \rightarrow \frac{0}{5}$ 突突范

웅 E

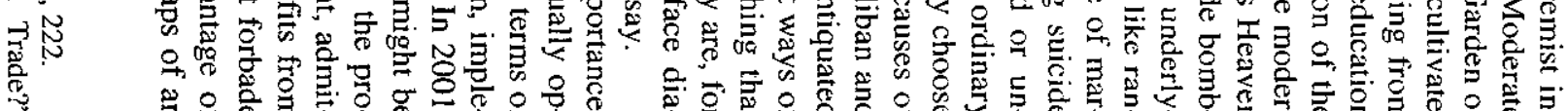

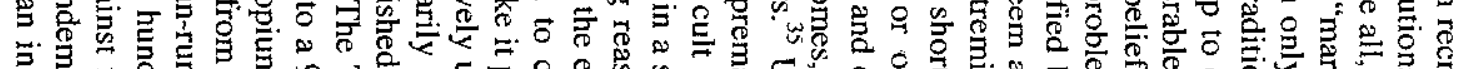

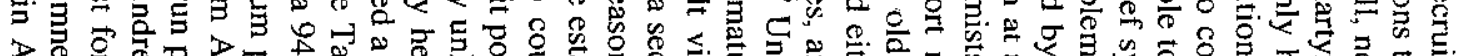

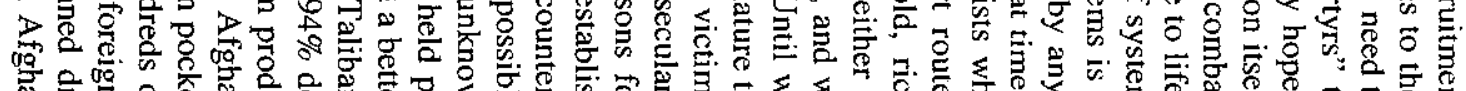

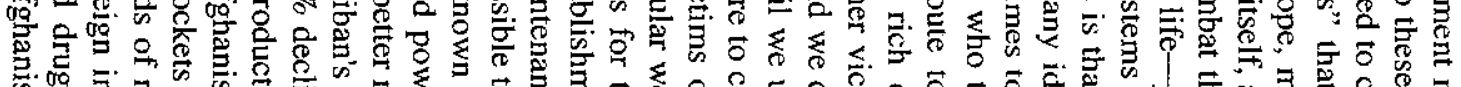

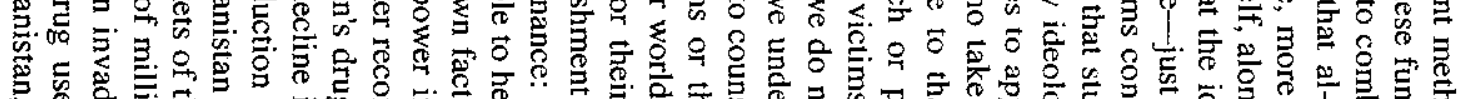

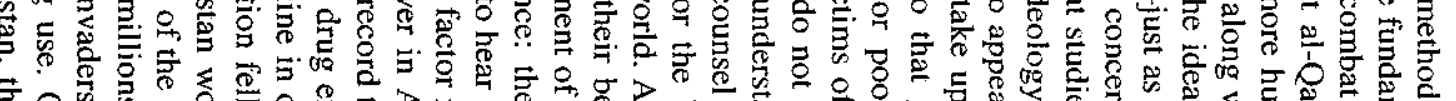

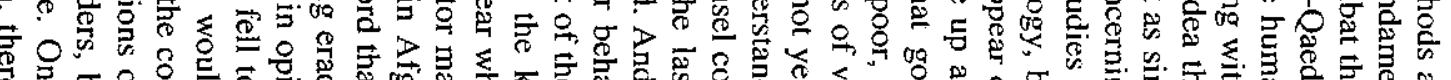

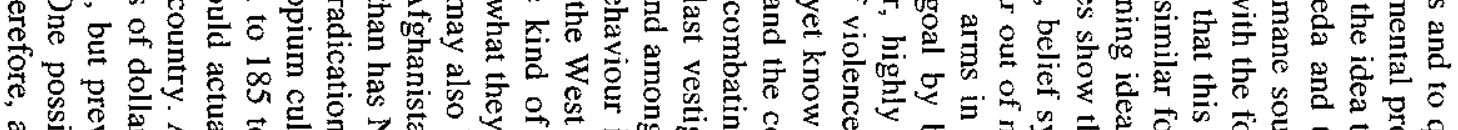

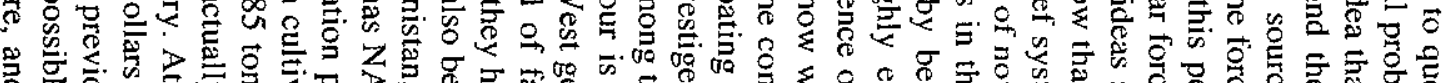

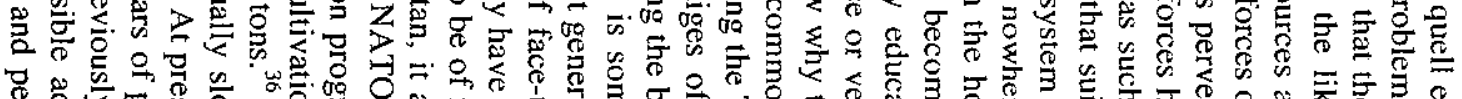

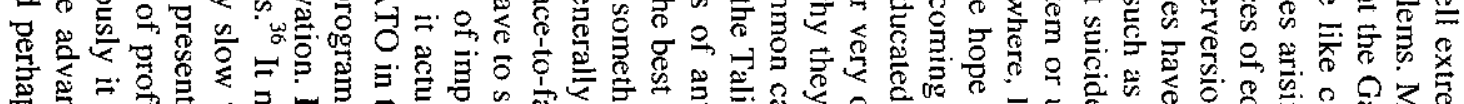

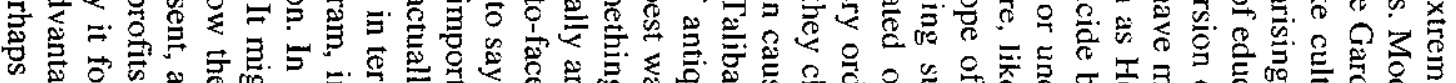




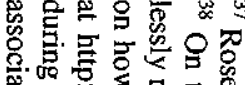

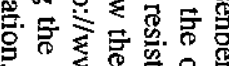
겅 证

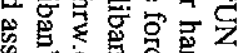

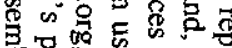

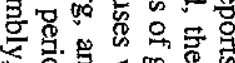

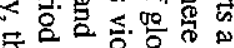
.

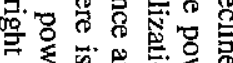

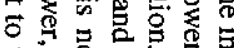

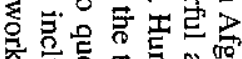
空 을 空星

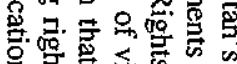
喟

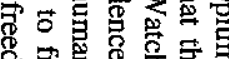
年

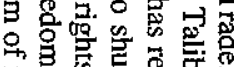

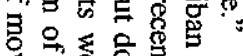
잉

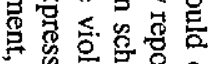

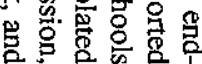

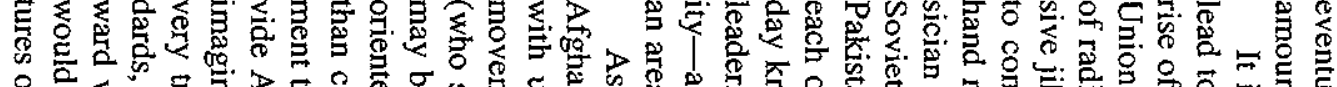

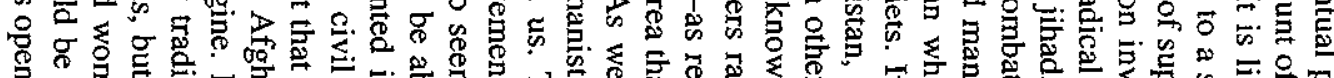

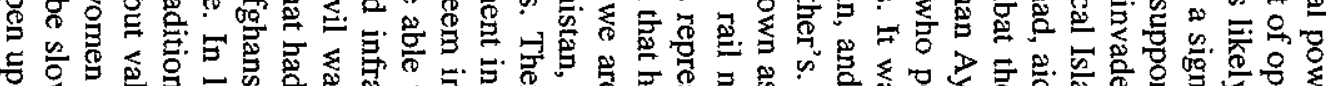

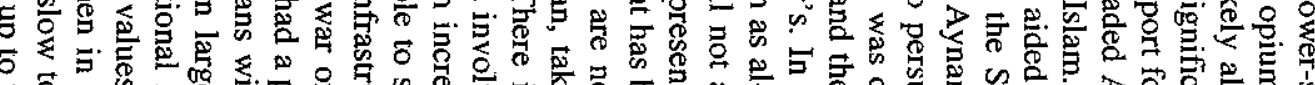

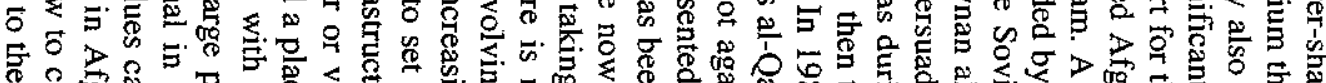

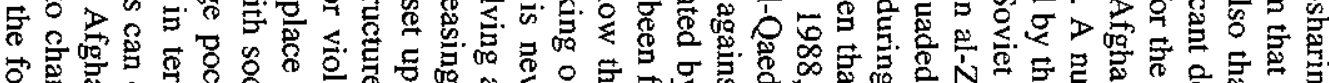

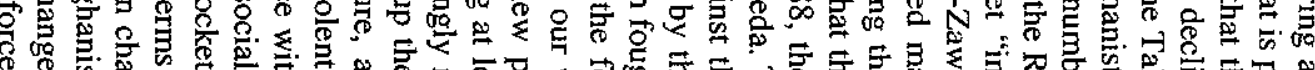

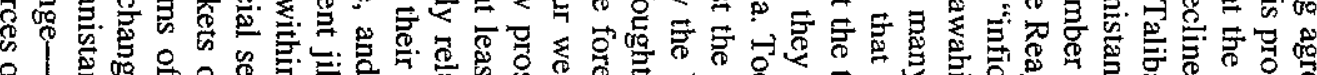

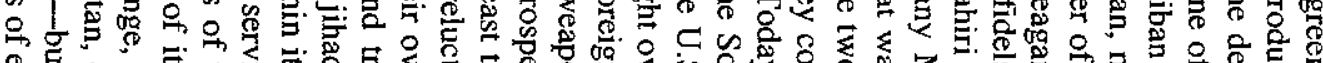

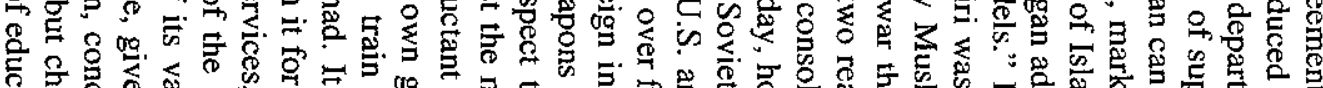

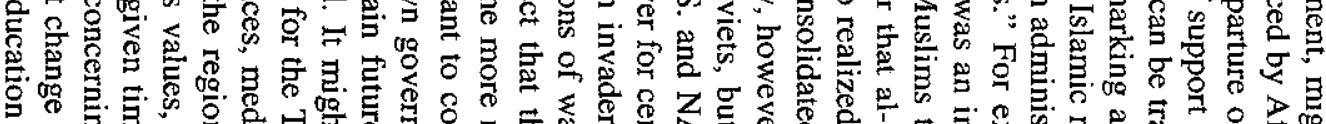

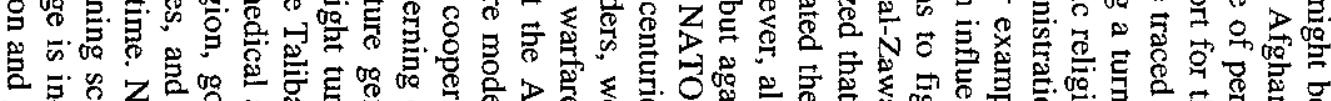

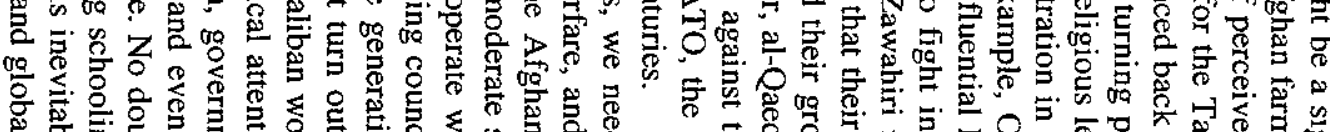

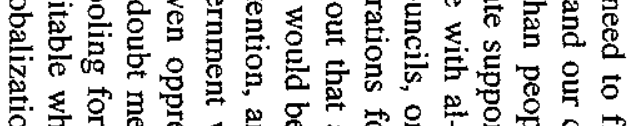

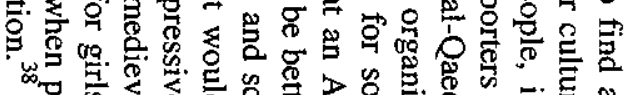

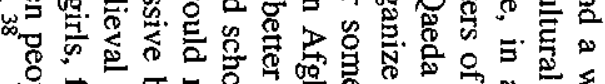

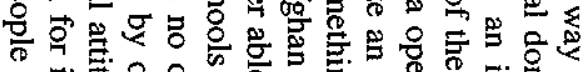

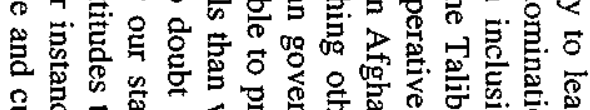

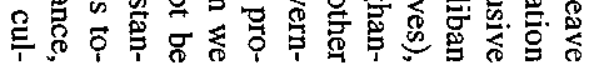

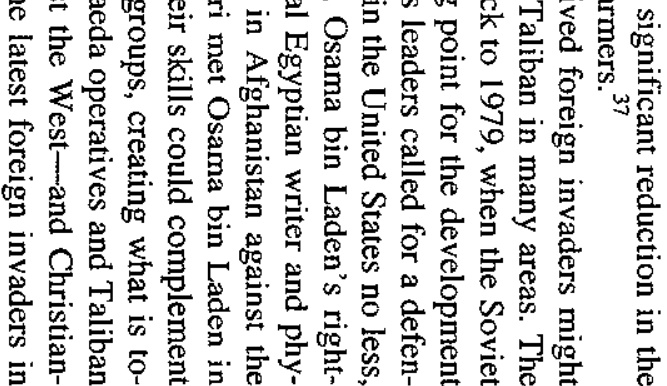

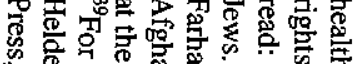

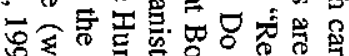
护品

. 열 要的 중

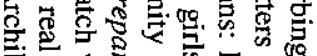

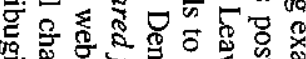

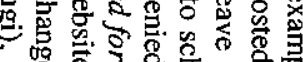

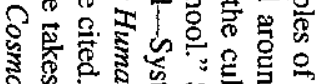
so

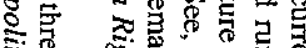

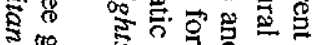

o

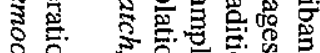

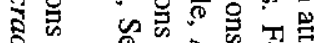

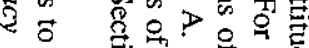
วิ을 का < 둥

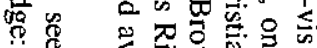
证

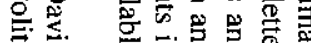

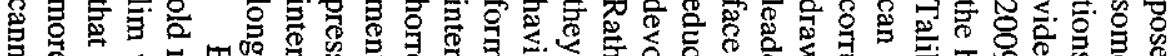

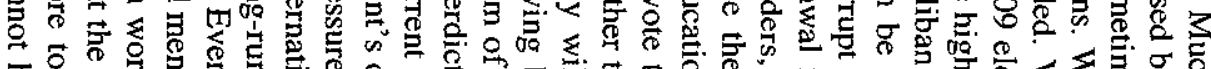

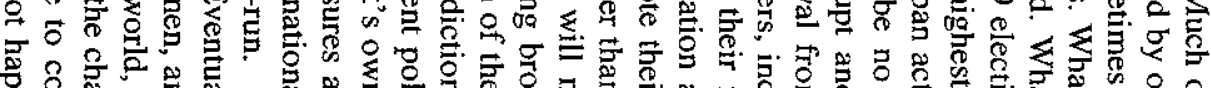

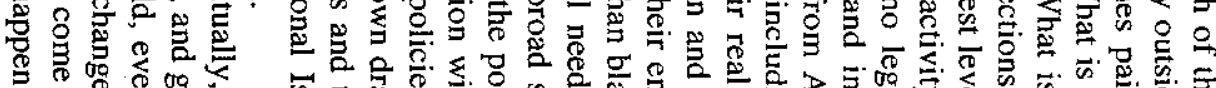

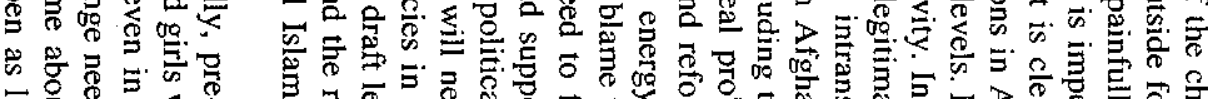

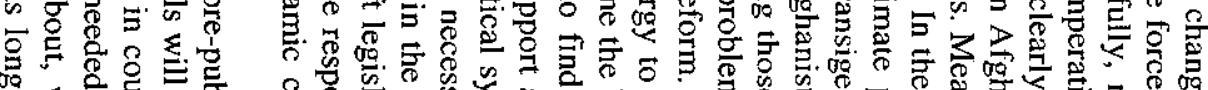

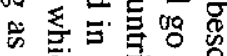

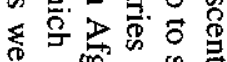

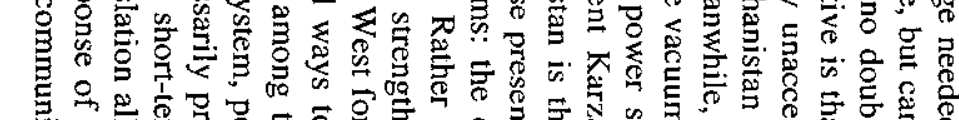

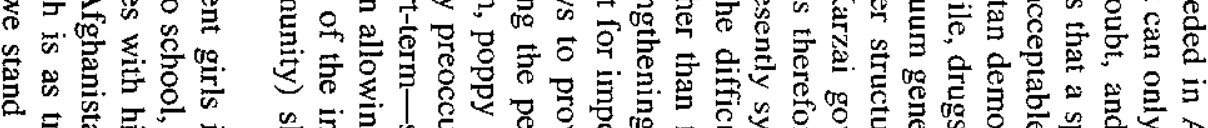

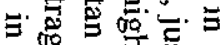

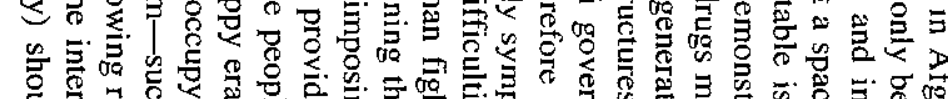

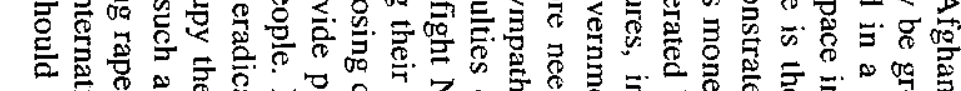
«

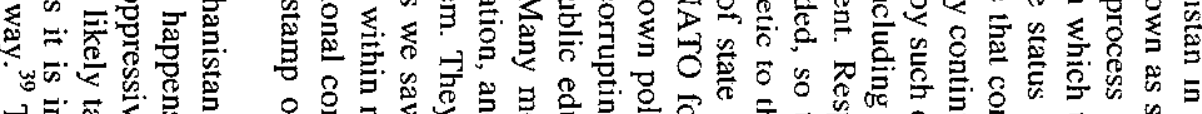

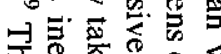

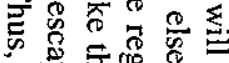

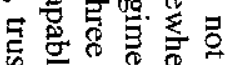

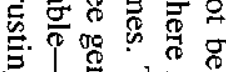
政

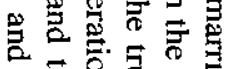

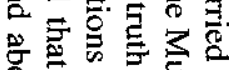

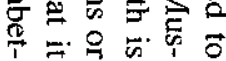

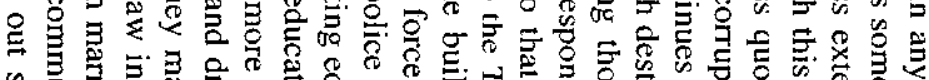

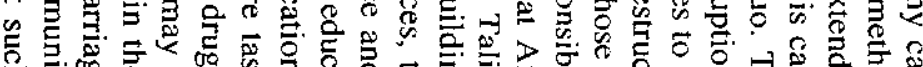

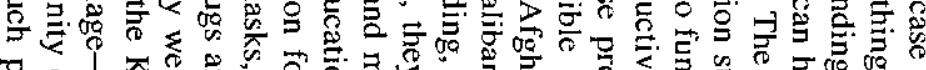

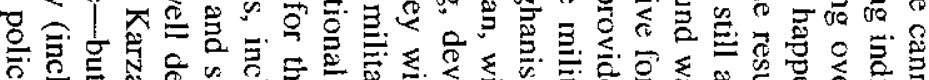

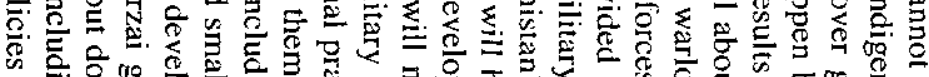

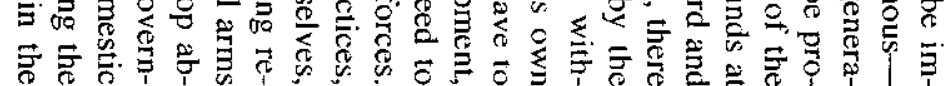

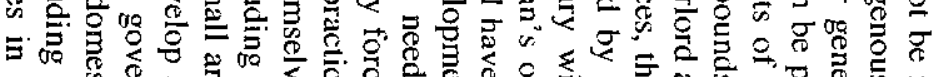




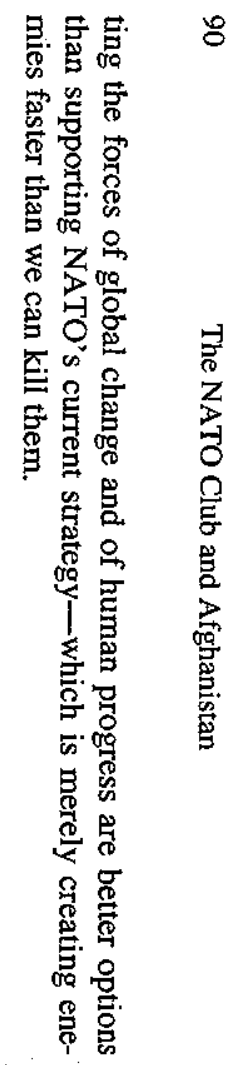

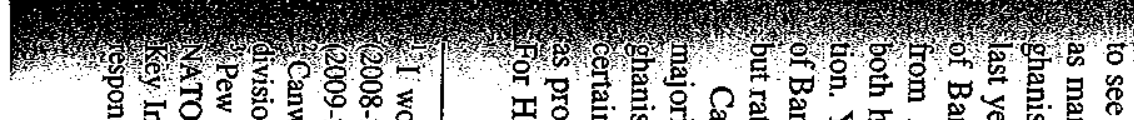

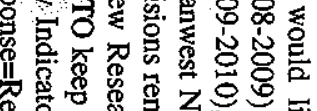

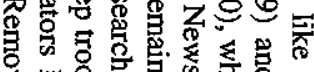

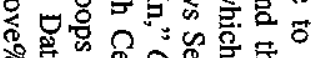

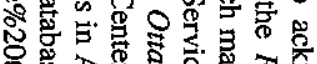

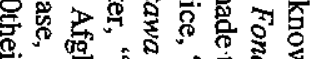

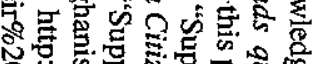

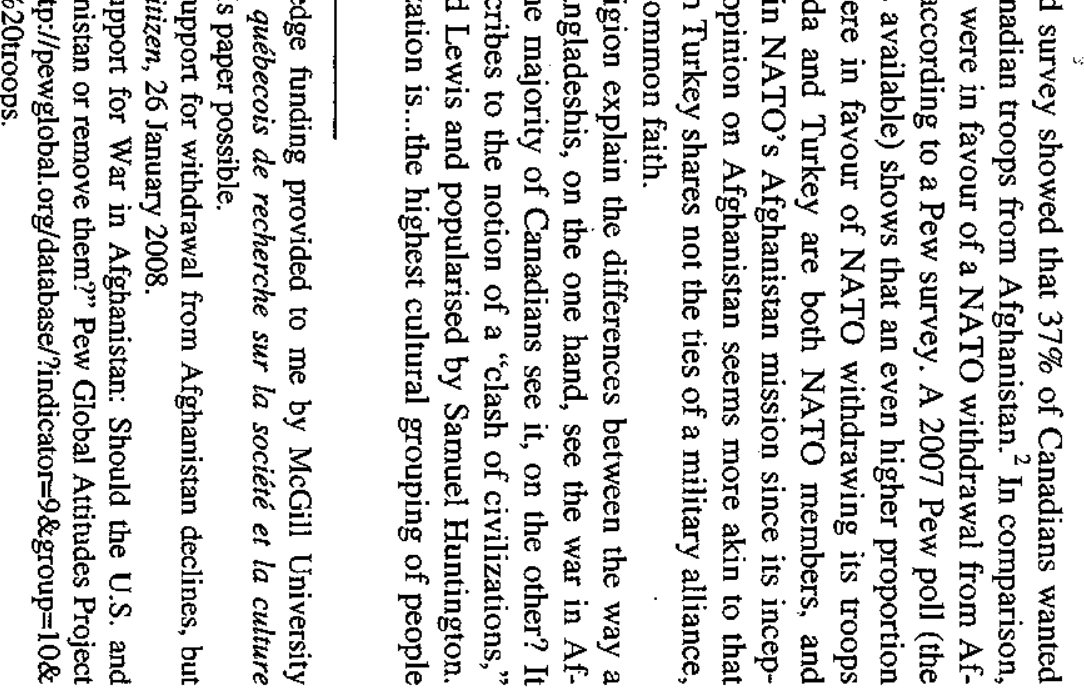

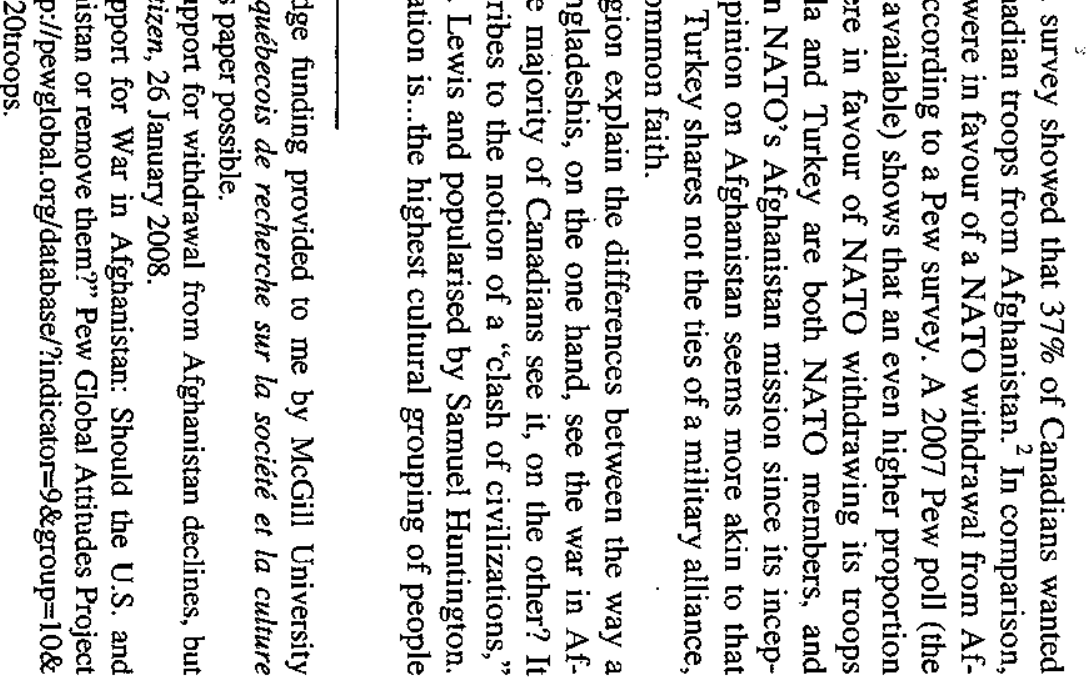

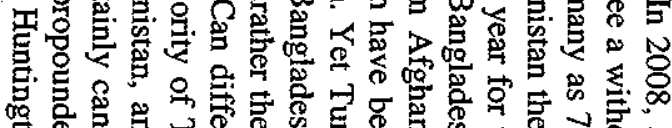

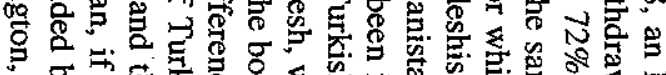

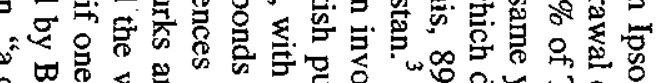

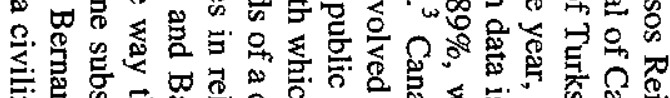

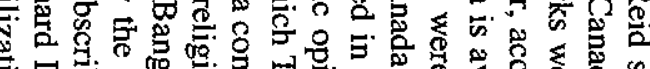

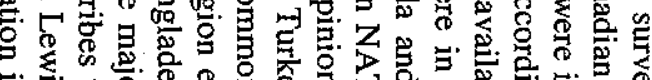
.

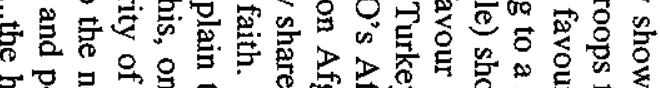

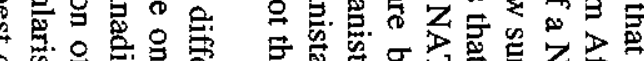

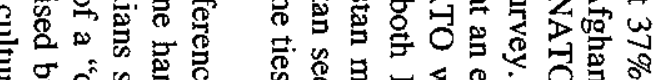

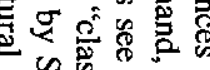

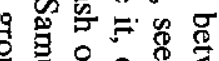
虽声范。

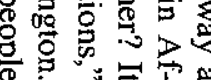

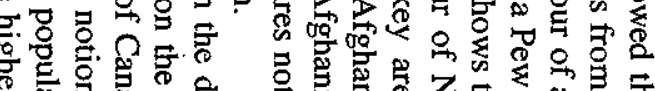

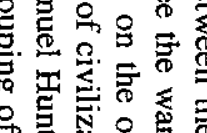

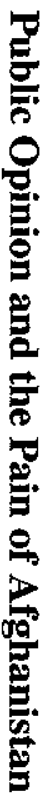
宁

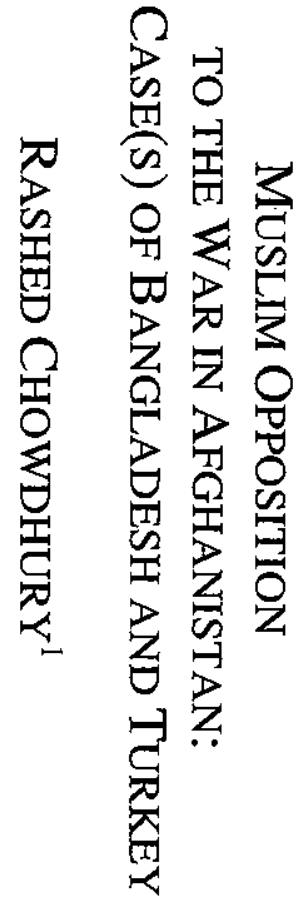

